Florida International University FIU Digital Commons

\title{
The Influence of the Guatemalan Municipal Orchestra's Curriculum on the Social Relations of its Members
}

Jacobo Nitsch

Florida International University, jnits001@fiu.edu

DOI: $10.25148 /$ etd.FI14071189

Follow this and additional works at: https://digitalcommons.fiu.edu/etd

\section{Recommended Citation}

Nitsch, Jacobo, "The Influence of the Guatemalan Municipal Orchestra's Curriculum on the Social Relations of its Members" (2014). FIU Electronic Theses and Dissertations. 1558.

https://digitalcommons.fiu.edu/etd/1558 
FLORIDA INTERNATIONAL UNIVERSITY

Miami, Florida

THE INFLUENCE OF THE GUATEMALAN MUNICIPAL ORCHESTRA'S

CURRICULUM ON THE SOCIAL RELATIONSHIPS OF ITS MEMBERS

A thesis submitted in partial fulfillment of the

requirements for the degree of

MASTER OF SCIENCE

in

MUSIC EDUCATION

by

Jacobo Nitsch Velasquez

2014 


\section{To: $\quad$ Dean Brian Schriner}

\section{College of Architecture and The Arts}

This thesis, written by Jacobo Nitsch Velasquez and entitled The Influence of The Guatemalan Municipal Orchestra's Curriculum on the Social Relationships of its members, having been approved in respect to style and intellectual content, is referred to you for judgment.

We have read this thesis and recommend that it be approved.

Cathy Benedict

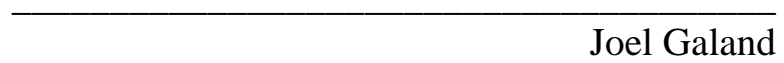

Joel Galand

Patrick Schmidt, Major Professor

Date of Defense: May 27, 2014

The thesis of Jacobo Nitsch Velasquez is approved.

Dean Brian Schriner

College of Architecture and The Arts

Dean Lakshmi N. Reddi

University Graduate School

Florida International University, 2014 


\section{ACKNOWLEDGMENTS}

It would not have been possible to write this thesis without the help and support of the kind people around me. I would like to thank:

To God for giving me the opportunity to study, to work, and to serve.

To my wife Vivi López for being the engine and inspiration every day throughout this journey.

To my parents, Pilar y Jacobo for instilling in me love and respect for humanity and social justice. To my Sisters María, Lucía and my niece Alejandra for their moral support.

To my advisor Dr. Patrick Schmidt for being my mentor, guide, and friend during this Masters program. To Dr. Cathy Benedict for bringing to my life different and keen perspectives for viewing life. During these two years, both of you, have facilitated an array of experiences that have influenced my evolution as an educator, musician, and more importantly, as a human being.

To my brothers from Malacates, especially Jorge Reyes, Paez and Leonel, for believing in my crazy and adventurous ideas. To Ari Nemser for his comradeship as a peer, musician and friend.

I would like to give a special thanks to Fulbright LASPAU and Florida International University for their financial, academic, and logistical support toward my studies. This opportunity has proven to be really beneficial, opening the doorways for strong future ties between Guatemala and The United States of America.

Lastly, but not less important, I am very grateful to The Guatemalan Municipal School of Music for its key support in the development of this research. 


\section{ABSTRACT OF THE THESIS \\ THE INFLUENCE OF THE GUATEMALAN MUNICIPAL ORCHESTRA’S CURRICULUM ON THE SOCIAL RELATIONSHIPS OF ITS MEMBERS \\ by}

Jacobo Nitsch Velasquez

Florida International University, 2014

Miami, Florida

Professor Patrick Schmidt, Major Professor

The purpose of this case study is to determine the influence of the curriculum used by the Guatemalan Municipal Orchestra (GMO) upon the social interactions of its members. Social interactions include relations with families, teachers, and music colleagues. To determine this influence, the researcher framed the study using three main components: the impact of music in the development of children's social skills; the curricula forming educational processes; and the characteristics of the Venezuela musical program, El Sistema. These foundations are explored via the tenets of participatory literacy. The data collection included interviews, surveys, and observation of students, parents, teachers, and administrative personnel. Two primary themes emerged from the data analysis: the development of a sense of community and the presence of intrinsic and external motivators implicit in the GMO environment. The final analysis suggests that curricular practices in the GMO positively influenced the development of students' social interactions. 


\section{TABLE OF CONTENTS}

CHAPTER

PAGES

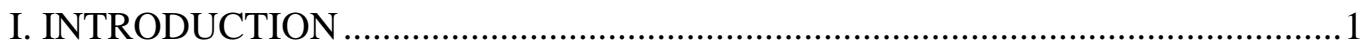

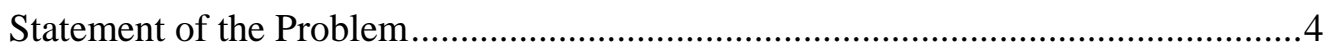

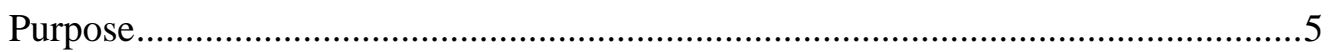

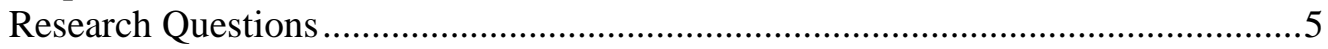

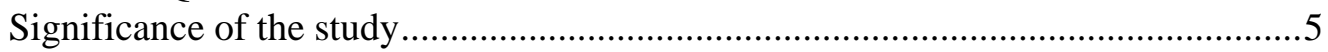

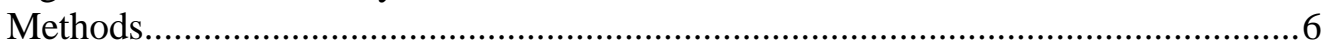

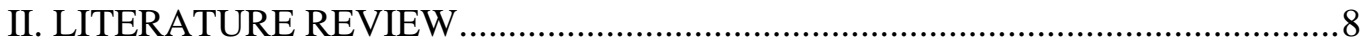

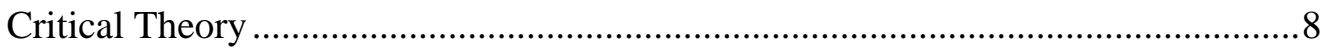

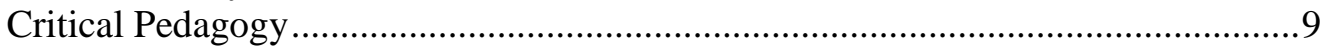

Paulo Freire and Critical Pedagogy. ............................................................11

Banking Education and problem posing. .....................................................12

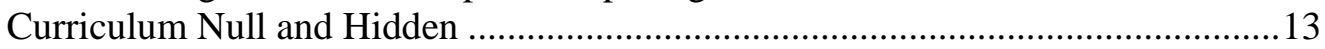

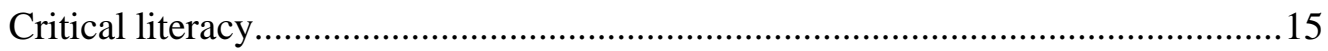

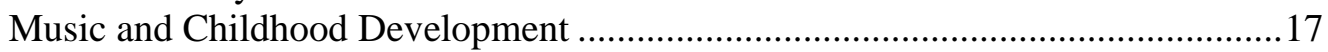

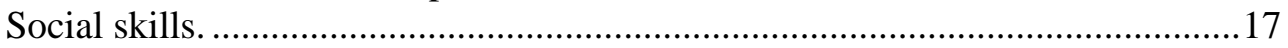

Social skills and music education. ..............................................................19

Group Learning and the El Sistema Model..........................................................20

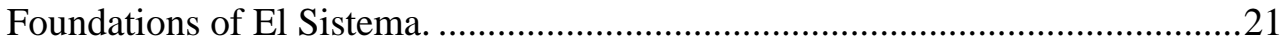

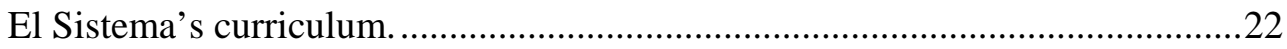

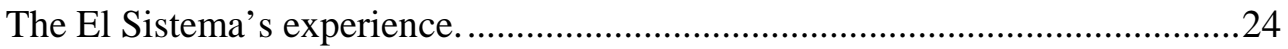

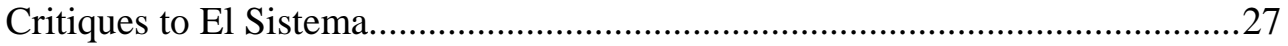

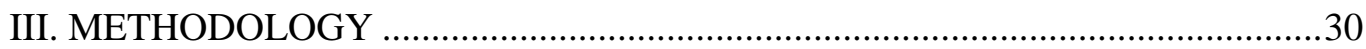

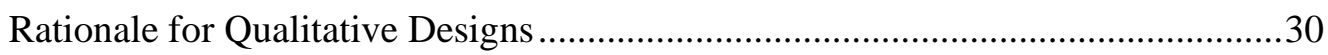

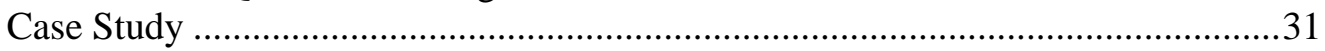

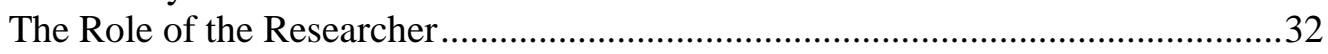

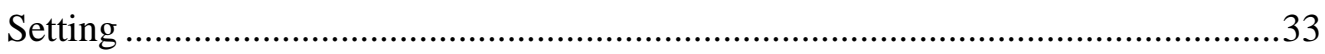

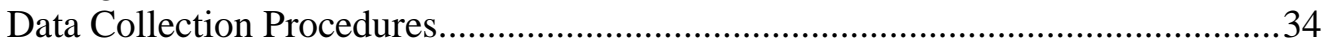

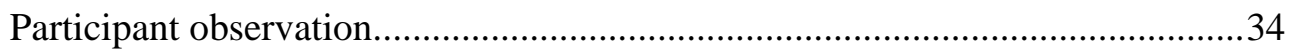

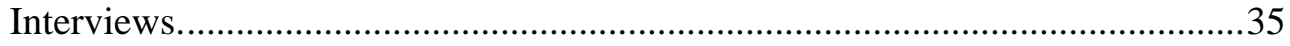

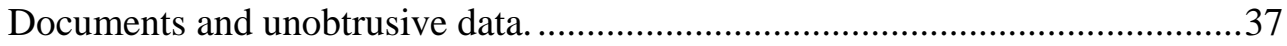

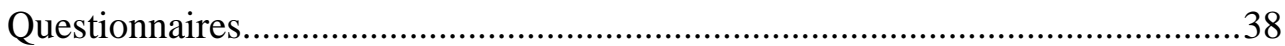

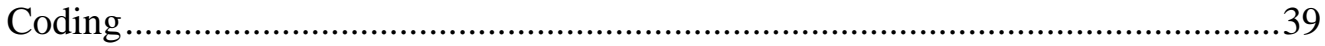

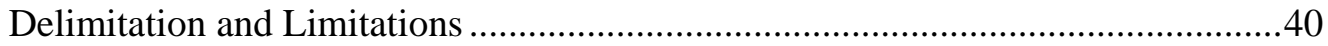

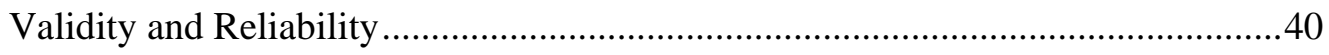

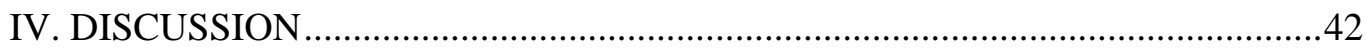

Conciertos de Barrio: Connecting Community with Classical Music .......................42

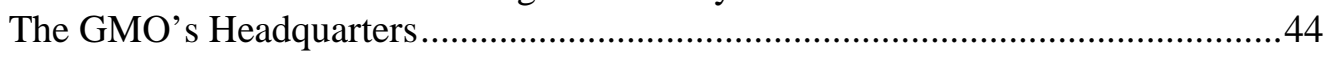

Evolution of the GMO: The Beginnings, Crisis, and Rebirth...............................48

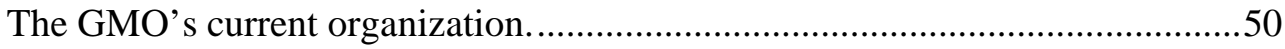

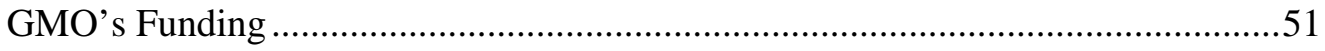

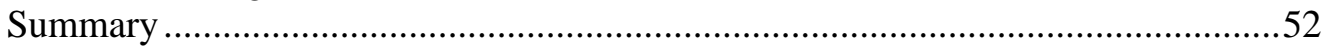




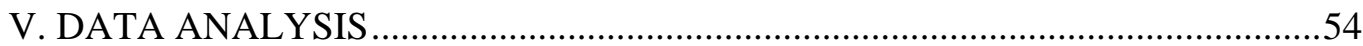

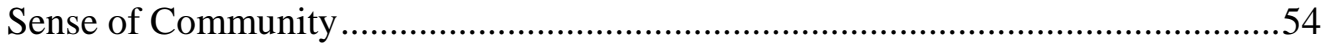

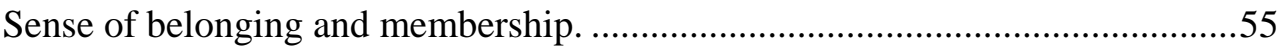

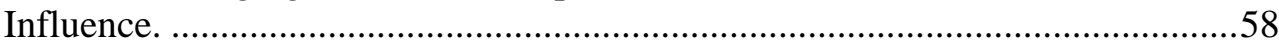

Influence inside of the GMO community..................................................58

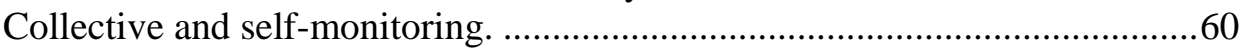

Member's influence on the GMO community................................................62

Curricular expansion: pursuing an academic degree. .....................................62

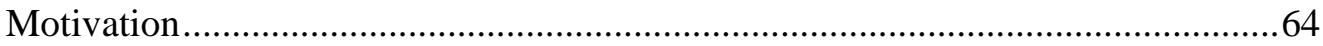

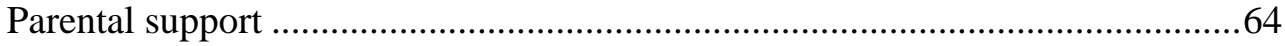

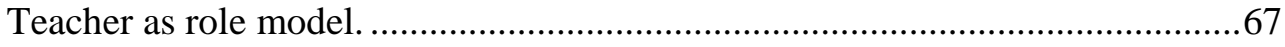

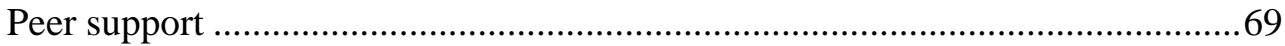

Musical aspirations as motivator. ................................................................73

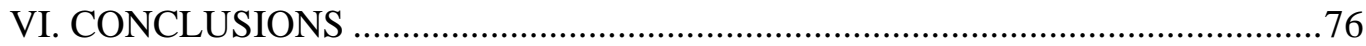

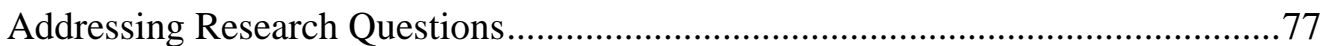

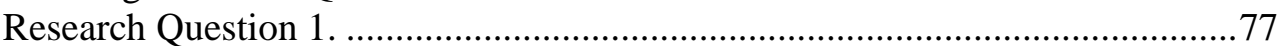

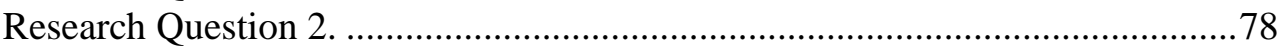

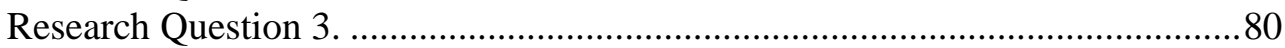

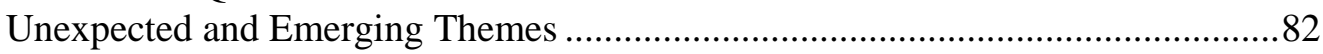

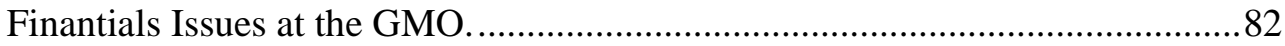

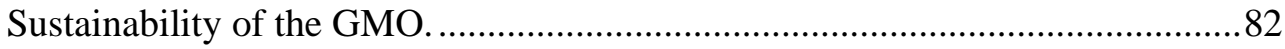

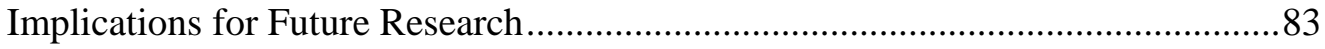

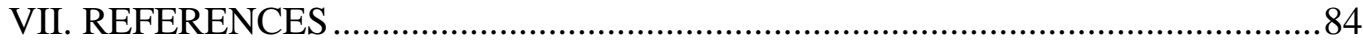

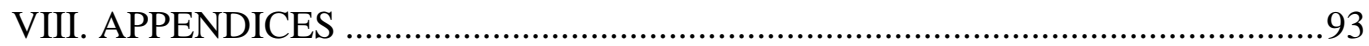




\section{INTRODUCTION}

The Guatemala Municipal Orchestra (GMO) is a music ensemble working with youth in underserved areas of Guatemala City since 2006. This orchestra is one of the nineteen musical groups of the Municipal School of Music, an education program based on the Venezuelan music program known as El Sistema (Escuela Municipal de Música, 2013). The press, governments, and international institutions all have linked the educational experience that the GMO provides to positive effects in the social life of its members (Archila, personal communication, September 23, 2013). Little empirical data exist to date, however, that corroborate such assumptions.

This study aims to determine the impact, if any, of the curriculum of the GMO upon the social interactions of its members. In order to determine this influence, the researcher framed the study using three main components: the impact of music in the development of children's social skills, the curricula forming educational processes, and the characteristics of the Venezuela musical program El Sistema. The study analyzes pedagogical practices within the GMO environment using the lens of Participatory Literacy, an educational approach and framework based on the tenets of critical pedagogy (Freire, 2000; Shor and Pari, 1999).

Numerous researchers claim that music education contributes to the development of perceptual skills, spatial reasoning, and fine motor coordination (Ackerman, 1996; Broh, 2002; Brown, 1980; Hallam, 2010; Marshall, 1978; Rauscher, 2009; Schellenberg, 2006). Likewise, Hallam (2010) states that an adequate music education may contribute to improving self-esteem, self-identity, and emotional sensitivity in children (Hallam, 2010). These are crucial to developing socialization among children, a process that occurs during daily activities, as well as in school, 
where the context is defined by pedagogical practices planned according to specific curricula.

The word curriculum may be defined from multiple perspectives. In education, where learning is the central activity, the interpretation of the word curriculum is "to view it as a course or plan for learning” (Andrade, 2000, p. 1). McNeil (1981) explains that curriculum could be defined according to the perspective of "what should be taught, to whom, when, and how" (p. 1). In this sense, Eisner (1994) claims the existence of "three curricula that schools teach" (p. 87). First and foremost, an explicit curriculum is stated in written form with clear goals, as, for example, when children are given clear objectives and procedures for reading, writing, and learning about the history of their country (McNeil, 1981). Secondly, an implicit or hidden curriculum exists when the learning that "occurs is not explicitly announced in school programs” (Bolodin, 2011, p. 5). Lastly, a null curriculum is neither explicit nor implicit and deals with what is systematically excluded from, neglected, or not considered within the expected curriculum (Bolodin, 2011, p. 5). This research addresses pedagogical practices in the GMO curriculum.

The GMO is the most prominent musical ensemble that includes the network of choirs and orchestras of the Guatemalan Municipal School of Music. The fundamentals of this institution are based on the philosophy of El Sistema, the Venezuelan System of Youth and Children Choirs and Orchestras. This program aims to foster the development and social organization of its members through individual and collective musical practice (Fundación Simón Bolívar, 2014, para. 1). Borzacchini (2010) points out seven premises underpinning the philosophic body of El Sistema: 1) Enjoyment and learning as social rights, 2) training, rehabilitation and social insertion, 3) individual, family and community integration, 4) material poverty 
defeated by spiritual richness, 5) music embedded in everyday life, 6) overcoming false musical paradigms, and 7) paths for meritocracy and country development.

Booth (2012) states that El Sistema "is a social change/youth development program that uses ensemble music to enable every child to experience being an asset within the community, in and out their 'núcleos'” —-musical centers—developing not just musicians, but also responsible citizens (para. 10). Different media and international institutions have attributed social benefits to the methodology of $E l$ Sistema, such as the improvement of self-confidence, team-work, leadership, selfworth, discipline, problem-solving skills, cooperation, coexistence, and societal benefits for the family, community, and nation (Menoscal, 2006). Although El Sistema (Venezuela) does not proclaim a fixed curriculum or methodology, its pedagogical practices and philosophy have inspired different musical programs worldwide: El Sistema USA (United States), Harmony (England), Big Noise (Scotland), Batuta (Colombia), Sistema Australia (Australia), and The Guatemalan Municipal School of Music among others.

Traditional education is often criticized for promoting quiescence: humans need to reconcile themselves to a specific place in a society that is pre-determined by the economical circumstances and social status in which they are born and raised (Popkewitz and Fendler, 1999). In contrast, critical pedagogy attempts to represent the voice of progressive educators who fight against these authoritative and deterministic types of education. This pedagogy criticizes traditional approaches to literacy whereby teachers only teach how to read words on pages and not how to read the world (Lankashear and McLaren, 1993). In contrast, critical pedagogy opens the path for a critical literacy that aims to empower teachers by attempting to connect the curriculum to student experiences, facilitating connections between what students 
learn in the class and their individual contexts (Kanpol, 1999). Participatory

interaction with texts and practices gives learners a new approach to understanding and changing their worldviews.

This new understanding of the world may be possible by achieving what Shor (1999) has called participatory literacy. This approach: starts with learners’ needs and interests; involves learners in determining the content of learning; focuses on meaning, not mechanics; centers instruction around themes drawn from learners' social reality; uses a variety of participatory tools to explore themes; moves towards action outside the classroom; and involves students in evaluation.

\section{Statement of the Problem}

Guatemala is a country with a land surface of 108,000 square kilometers and a population of more than 15 million (Instituto Nacional de Estadística de Guatemala, 2014). During the last two decades, Guatemalans have been facing various economic, political, and social problems, evidenced in the high indexes of poverty and violence (Instituto Nacional de Estadística de Guatemala, 2014; Unicef Guatemala, Violencia y corrupción, para. 1). Striving for social change among at-risk youth and children, the Guatemalan Municipal School of Music was founded under the same philosophical ideals as El Sistema.

Currently, the Municipal School is catering to more than two thousand children distributed among six nucleus [centers of musical development]. These centers comprise multiple ensembles, building a network of more than fifty-two choirs, bands, and orchestras. Within the Guatemalan Municipal School of Music, the GMO ensemble stands as the highest point in the hierarchy of this network. According to Archila (2013), the GMO's main objective is to transform the reality of 
its members by promoting moral values such as discipline, responsibility, and solidarity through a musical experience.

Many teachers and representatives claim that the active participation of youth and children in the activities of the GMO yields positive effects on their social development. While the academic director of the GMO considers that the program improves the lives of the participants, the challenge of precisely identifying the impacts of the experience, as they relate to curricular role and context, remains a relevant and unaddressed issue.

\section{Purpose}

The purpose of this study is to determine the impact and influence of the GMO's curriculum upon the social interactions of its members. Social interactions include relations with their families, teachers, and music colleagues.

\section{Research Questions}

The following questions frame this research:

1. How do youth participating in the GMO perceive the curricular structure of the program and how it facilitates social interactions?

2. How do teachers participating in the GMO perceive the curricular structure of the program and how it facilitates social interactions?

3. How does the leadership of the GMO perceive the curricular structure of the program and how it facilitates social interactions?

\section{Significance of the study}

This study investigates what influence the musical curriculum of the GMO has on its children and young members. The absence of reliable and empirically collected data on GMO establishes the significance of this study. A document reflecting the GMO curriculum and its impact on Guatemalan children and youth provides an 
evidence-based resource for future decision-making while highlighting elements and characteristics of the program previously known only anecdotally. The data and analysis established by the current study might lead to:

- Improving the current GMO curriculum

- Advocating for other music centers with this curriculum

- Initiating a research program about Guatemala’s musical ensembles

- Justifying the opening of these musical centers nationwide, at a time when the government of Guatemala is not supporting these kinds of projects on a large scale.

- Helping raise awareness in Guatemalan society of art's role in developing good citizens.

\section{Methods}

Since the aim of this study is to better understand the perceptions that youth, teachers, and leadership have about the curriculum of the Guatemalan Municipal Orchestra, a qualitative research approach was chosen to frame the inquiry. Creswell (2009) portrays qualitative research as a "means for exploring and understanding the meaning individuals or groups ascribe to a social or human problem” (p. 4), a framing structure appropriate for this investigation.

A case study was the qualitative design selected. The Case Study is an “intensive description and analysis of a phenomenon or social unit such as an individual, group, institution, or community” (Merriam, 2002, p. 8). Data collection consisted of observations, interviews, surveys, and unobtrusive data. Observations were conducted during one concert and four days of normal GMO activity, which included rehearsals, lessons, and recreational time. As part of this study triangulation, 
I administered surveys to both parents and students. Twenty-two study participants were interviewed, including students, teachers, parents, and administrative personal. I collected one curricular proposal, three informative pamphlets, and several articles in local newspapers. For Data Analysis, I used Axial Coding, which consists in organizing information by themes and subthemes and then making conceptual connections (Grbich, 2012). 


\section{LITERATURE REVIEW}

The following three elements underpin the current literature review. The first explores the fundamentals of participatory literacy and is based on the tenets of Critical Pedagogy, an educational framework that provides the central lens for the data analysis developed below. The second addresses the notion that music is influential on the development of social skills of children and youth, and the third consists of a description of The National Network of Youth and Children's Orchestras and Choirs of Venezuela, globally known as "El Sistema" The development of these three themes will facilitate an understanding of the context and findings of this investigation.

\section{Critical Theory}

In order to address the impact of social interactions and to contextualize participative literacy this literature review starts with an analysis of Critical Theory. Critical Theory was first associated with the theoretical tradition initially developed by the Institute of Social Research at University of Frankfurt in the 1920's and 30's, which became known as the "Frankfurt School”. It was built on the ideas of renowned theorists such as Max Horkheimer, Theodore Adorno, and Herbert Marcuse (Blake and Masschelein, 2002; Held 1980; Zou and Trueva, 2002). After World War I and the resulting German economic debacle, these thinkers found it necessary to reinterpret existing social and political conditions, drawing upon a reinterpretation of social precepts first rationalized by philosophers such as Marx, Kant, Hegel, and Weber. After Hitler's climb to power, several of these critical theorists immigrated to the United States, where they continued developing their work, providing the "philosophical voice of a new left" that was crucial for different political and cultural 
revolutions, although they themselves tended to view activist politics with a jaundiced eye (Zou and Trueba, 2002, p. 88).

Popkewitz and Findler (1999) succinctly define this complex approach, saying, "Critical theory is a reflection on the relationship between an individual and society” (p. 69). Pertinent to this study and its framework, critical theory, in its many forms and its vast reach, addresses such issues as the dependence of social institutions on the economy, the power of art as a tool for manipulating the masses, the distinction of social classes, alienation, cultural imperialism, and ideology (Cary, 1998). Thus, it provides a social critique aligned with key social, political, and economic challenges of the 20th century and still pertinent today.

Critical Theory continues to provide a lens for social critique, and that lens has naturally widened to take in the realm of Education. Cary (1998) explains that "in few realms has the hierarchical structure of inequality become more firmly entrenched than our schools” (p. 39) and therefore the investigation of power and social relations in schooling and similar learning organizations remains pertinent. Regarding educational research, Zou and Trueba (2002) explain that critical theory “does not determine how we see the world but helps us devise questions and strategies for exploring it” (p. 90). During the last four decades, educators have adopted critical theory in different ways, with critical pedagogy being one of most prominent subcategories used to challenge the structural, instructional, and social problems embedded in the process called schooling.

\section{Critical Pedagogy}

Critical pedagogy has emerged from critical theory, establishing itself as a philosophical stance that focuses on understanding the observable relationship between political power and schooling. While critical pedagogy claims that human 
beings "are essentially un-free and inhabit a world rife with contradictions and asymmetries of power and privilege” (McLaren, 2003, p. 193), traditional education often promotes the idea that humans need to reconcile themselves to a specific place in society, pre-determined by socio-economic milieu in which they were born and raised (Popkewitz and Fendler, 1999). By contrast, critical pedagogy attempts to represent the voice of progressive educators who fight against these authoritative and deterministic forms of educational structures.

Many authors share the view that critical pedagogy neither comprises a set of homogeneous ideas nor constitutes a formal comprehensive theory of learning and teaching in and of itself (Freire, 2011; Kanpol, 1999; McLaren, 2010; Morrow and Torres, 2002). Indeed, Popkewitz and Fendler (1999) describe critical pedagogy as:

An effort to raise questions about inequalities of power, about the false myths of opportunity and merit for many students, and about the way belief systems become internalized to the point where individuals and groups abandon the very aspiration to question or change their lot in life. (p. 50)

Critical pedagogy thus proposes an education that challenges the assumptions and outcomes "taken for granted” by dominant culture through conventional education (Gruenewald, 2003, p. 3). Furthermore, this pedagogy brings to the table a new and critical perspective for future inquiries into the benefits as well as the disadvantages of traditional educational constructs. Specific to this project, the philosophical bent and discourse of critical pedagogy can be detected in some of the language of social justice and ‘social rescue’ proposed by El Sistema, and consequently also influences the current investigation into the effects of curricular practices within the Guatemala Municipal Orchestra.

This is significant in the context of this investigation because Guatemala is a country displaying both a vast cultural diversity and distinctly marked socio- 
economic differences between its inhabitants (Segeplan, 2014). Even though Guatemala’s constitution guarantees education and primary necessities for every Guatemalan, statistics show high rates of violence, starvation, poverty, and illiteracy (Segeplan, 2014). In light of this crisis, the goal of this study is to use critical pedagogy, and more specifically participatory literacy, to frame the analysis of the Guatemalan Municipal Orchestra, thus questioning both the purposes and the effects of its curricular practices upon the lives of its members.

Paulo Freire and Critical Pedagogy. There are several authors associated with the development of Critical pedagogy, such as Henry Giroux, Peter McLaren, Ira Shor, and of particular prominence, Paulo Freire. This Brazilian thinker is widely known for his work Pedagogy of the Oppressed, a seminal book that comprises his reflections on adult literacy and learning emergent from his work and lived experiences in Brazil. He is considered to be perhaps the founder and certainly one of the most important developers of critical pedagogy’s tenets. In "Reinventing Paulo Freire,” Antonia Darner (2003) defines critical pedagogy as "becoming aware of who you are, your past and how you can change what is happening to you and your surroundings” (p. 233). Freire’s legacy encourages the development of “a consciousness of freedom, to recognize authoritarian tendencies, to connect knowledge to power and agency, and to learn to read both the word and the world as part of a broader struggle for justice and democracy” (Giroux, 2011, p. 152). These critical features challenge traditional order in social institutions such as schools, universities, enterprises, and governments, encouraging a collective and individual transformation of reality.

Freire asserts that this transformation is possible only through an awareness of our reality and a purposiveness in seizing control of what we do, what we think, and 
what we want to become, a complex process that he called "conscientization" (Blackburn, 2000; Freire Institute, 2014; The Arizona University, 2012). This process has been defined as "learning to perceive social, political, and economic contradictions, and to take action against the oppressive elements of reality” (Grueneval, 2003, p. 4). In order to promote conscientization, and based on his experiences with adult literacy, Freire advocated for a direct and overt relationship between text and contextual reality, what he called "word to world relations.” He argues that by reading the world and reading the word, teachers and students can engage in praxis, i.e., the "reflection and action upon the world in order to transform it" (Freire, 1972, p. 33). A new kind of education emerges from both the praxis of conscientization and the reading of world and word based on a new dialogue among students, teachers, and the environment where knowledge is produced, particularly by focusing on the uncovering and resolving of different kinds of problems.

Banking education and problem posing. Through the critical pedagogy lens, Freire distinguishes between two types of education, ”banking education” and “problem posing.” Banking education occurs when teachers deposit ideas and knowledge into students, who assume a voiceless, patient, and passive attitude (Freire, 2011). In this type of education, the teacher is at the center of the learning process, assuming the position of authority as an expert, lecturer, and executor of discipline, while the students are merely present, having been given no opportunity to make critical decisions or give alternative opinions (Canestrari and Marlowe, 2004; Freire, 2011; McLaren, 2003).

Conversely, problem posing offers a different approach to education by which the learner critically uncovers his or her reality, actively interacting with teachers and peers. Freire describes problem posing as an "authentic or liberating kind of education 
wherein [the] teacher becomes student, and vice versa, using a horizontal dialogue to make the educational process more active” (Roberts, 2000, p. 54). This kind of critical education could be observed in and applied to different educational settings.

From the lens of critical pedagogy, "schools are cultural and political spheres, they actively engage in the production of both cultural and societal norms, values, knowledge, and language” (McLaren and Kincheloe, 2007, p. 231). Music education plays an important role in the creation and growth of diverse aspects of culture such as ideals, attitudes, practices, and behaviors (Abrahams, 2012). Thus, music has implicit the power and the possibility to change, to transform and to emancipate societies through the development of critical music awareness (McLaren and Kincheloe, 2007). Furthermore, Abrahams (2005) explains how critical pedagogy in music education "seeks to identify possibilities in the classroom by offering schema to connect word to world and by its unyielding urgency of transformation” (p. 8). In this sense, sound is the analogy of word by which we might read the world through music. Critical literacy is the medium to encourage the reading of the world through the critical analysis of words and symbols. Given that the focus on this study is the exploration of curricular impact upon social interactions of students, we now turn to curriculum, remaining grounded in a critical evaluation of its potential and limitations.

\section{Curriculum Null and Hidden}

There are a myriad of approaches to define the word "curriculum.” Etymologically, Dan (2003) explicates that the Latin word for curriculum means “course” or " track to be followed”, thus, in education, where learning is the central activity, the "most obvious interpretations of the word is then to view it as a course or plan for learning” (p. 2). This organization of knowledge is the backbone of the 
education process, once it prescribes what and how education would be developed (Andrade, 2000). McNeil (1981) explains that curriculum, in educative matters, could be defined according to the perspective of "what should be taught, to whom, when, and how” (p. 1). The author distinguishes between four major orientations in curriculum: 1) The Humanist view concerns itself with the development of the individual; 2) The Social Reconstructionist view that considers the development of society and its political and economic relationships with curriculum development; 3) The Technological view emphasizes the efficient use of new technologies in the achievement of educative goals; and 4) The Academic view where scholars select goals contents and recommend teaching activities within the traditional curriculum (McNeil, 1989; McNeil, 1996; McNeil, 2006). Kelly (2009) points out that although it is possible that every curriculum approach could be effective in achieving specific objectives, all of them should be framed by a total curriculum, that is, the conception of the world as a totality.

Eisner (1994) claims the existence of "three curricula that all schools teach" (p. 87). The first one is an explicit curriculum established in public goals. For example, it might be mandated for "children to read and write, to figure, and to learn something about the history of the country among them” (p. 87). The second is a "null” curriculum that entails that which is systematically excluded, neglected, or not considered (Bolodin, 2011, p. 5). Bolodin (2011) cites as an example curriculum where the greatest literature may just include works written by European males, thus excluding works from other genders and cultures. Eisner (1985) stresses the equal importance of this process of selection and discrimination of knowledge, i.e., "what schools do not teach and what they do teach” (p. 97). The third curricular notion is an implicit or hidden curriculum that refers to the "learning and interaction that occurs 
that is not explicitly announced in school programs” (Bolodin, 2011, p. 5). This “hidden” curriculum has also being defined by McNeil (1981) as, “intentional outcomes from schooling that are not [openly] recognized.” These outcomes "are unofficial instructional influences, which may either support or weaken the attainment of manifest goals” (p. 236). Likewise, Santos (2004) defines hidden curriculum as "the set of norms, customs, beliefs, languages and symbols that appear in the structure and operation in an institution” (p. 4). From the lens of critical theory, Giroux (2001) stresses the significance of hidden curriculum identifying "schools as political institutions, inextricably linked to the issues of power and control in the dominant society” (p. 87). Such issues emerged from the teaching and practicing of a complex of "norms, values, and the belief systems throughout the curriculum, the school and classroom life” (Kentli, 2009, p. 86).

Under the lens of critical pedagogy, and specifically form Critical literacy discussed in the following section, individuals can be encouraged to become more aware of different aspects included in the hidden curriculum, engaging teachers and students in a more democratic process of uncovering established hegemonic practices and norms (Wallowitz, 2008).

\section{Critical literacy}

The concept of critical literacy is also grounded in the work and lived experiences of Paulo Freire, who criticizes traditional literacy approaches in which teachers only teach students how to read words on the page, and not how to read the world; thus, engendering literate students in a technical sense of the word, but allowing them to remain as passive humans beings rather than active subjects of history (Lankashear and McLaren, 1993). Kanpol (1999) explains that there is a “moral obligation” from schools to prepare literate students ready to engage with the 
acquisition of goods and services that society offers (p. 54). This preparedness goes beyond the normative product of a functional literacy that has implicit the mastery of specific skills for the decoding of different signs such as words and numbers.

Freire portrays critical literacy as an alternative way of learning, which helps people to liberate them from oppression, to be conscious about reality and to change it (Freire, 2011). In this sense, critical literacy today is not a set of cognitive dexterities to be developed in individual minds, "but as a socio-culturally situated practice involving the ongoing negotiation of meaning in continuously contested sites of meaning construction, then all literacy in a certain sense ought to be critical” (Chen and Belgeonne, 2007, p. 4). Critical literacy empowers teachers to connect curriculum to student experiences, producing learning experiences that facilitate connections of what is learned in the class with their reality (Kanpol, 1999). Morrell (2002) explains that the critically literate "can understand the socially constructed meaning embedded in texts as well as the political and economic contexts in which texts are embedded" (p. 73). The participative interaction with texts, gives to learners a new approach in how to understand and change their worldviews.

This new understanding of the world may be possible by the achievement of what Shor (1999) has called "participatory literacy.” This approach starts with the learner's needs and interest involving learners in determining the content of learning, focusing on meaning, not mechanics, contextualizing work on form, centering instruction around themes drawn from learners' social reality, encouraging dialogue and critical analysis of social realities, using a variety of participatory tools to explore themes, moving toward action outside the classroom, and involving students in evaluation. These characteristics have served as theoretical lens for this investigation 
where was determined if and how pedagogical practices of GMO could impact the life of students.

\section{Music and Childhood Development}

It is claimed that music education is vital to the growth and development of children (Rausher, 2003). Hallam (2010) argues that based on previous investigations, music develops perceptual skills, spatial reasoning, fine motor coordination, and consequently it has an indirect impact on literacy and numeracy. Likewise, an adequate music education can facilitate children’s self-esteem and identity by increasing their emotional sensitivity, which, in turn, can impact the acquisition and development of social skills (Broh, 2002; Brown, 1980; Hallam, 2010; Marshall, 1978; Rauscher, 2009). As aspect of growth and development in children and youth are many, for the purposes of this study, the current literature focuses solely on the notion of social skills.

Social skills. Social skills are understood as a series of interactions between individuals and their environment through the acquisition of specific abilities that improve competency in social situations (Elliot and Greshman, 1987; Matson, 2009; Merrell and Gimpel, 1998). Michelson (1983) identified six main features of social skills. They are primarily acquired through learning and a) are comprised of specific and discreet verbal and nonverbal behaviors; b) entail effective, appropriate initiations and responses; c) maximize social reinforcement from others; d) are interactive in nature, and require appropriate timing and reciprocity of specific behaviors; and e) are influenced by environmental factors such as the age, sex, and status of the other person (Owen, 1981, pp. 2-3).

Elliot and Greshman (1987) identify three different definitions of social skills.

The first includes peer acceptance, where individual are labeled as socially skilled 
regarding their acceptance by peers. The second definition is behavioral, and considers social skills as specific behaviors that are "more likely to be reinforced and less likely to be punished” (Matson, 2009, p. 3); The final definition is social validity, which is comprised of peer acceptance and behavior, considering social skills as “those behaviors exhibited in specific situations that help in predicting a child’s attitude on important social outcomes” (p. 96). These social outcomes include: acceptance by the peer group, significant others' judgments of social skills, academic competence, adequate self-concept or self-esteem, and adequate psychological adjustment (Elliot and Greshman, 1987).

On the other hand, diverse implications have been attributed to the deficit of social skills attainment, such as: school maladjustment, dropping out of school, juvenile delinquency, mental health difficulties, loneliness, depression, aggression, poor academic performance, and difficulties in interpersonal relationships with parents, teachers, and peers amongst others (Asher and Hymel, 1981; Cava and Musitu, 2001; Gresham, 1981; Gresham, 1990; Halpern, 1995; Hutchings, 1991).

Children and adolescents acquire social skills from interacting with different people—-parents, acquaintances, peers, friends, and teachers in different environments such as home, school, sports team, and arts groups. Rubin, Bukowski and Parker (2007) explain that these experiences could be better understood through analysis of the levels of social complexity in individuals, in interactions, in relationships, and in groups. Rubin et al. (2007) define interaction as "the social exchange of some duration between two individuals” (p. 576). More complex relationships and friendships involve meanings, expectations, and emotions derived from a series of successive interactions (Rubin et al., 2007). 
Social skills and music education. Music plays a very important role in the everyday life of individuals, especially upon the development of social skills. Hargreaves and North (1999) claim that regardless of whether or not an individual is a musician, a person can discover the social functions of music in three principal ways: 1) self-identity, the expression of identity and opinions through the music; 2) interpersonal relationships, the desire to fit in specific social groups through the conformity in musical preferences; and 3) mood in everyday life, the use of music for mood management. Two such examples would include exercising with music to alleviate pain, or using music as a means to influence customers in a shopping environment.

Musical practices at school have an implicit impact on multiple social interactions, which can shape the development of children and youth’s social skills. Hargreaves, Marshall and North (2003) state that the majority of musical practices "are carried out with and for other people — it is fundamentally social— — and so can play an important part in promoting interpersonal skills, teamwork, and co-operation” (p. 160). According to the National Association for Music Education (2012), learning music in school contributes to the overall success students have in school, society, and life. Gooding (2011) lists several social aspects involved in different music making processes: “cooperation, communication (verbal and non verbal), positive peer interactions, peer collaboration, recognizing and supporting the rights of others, dependability, responsibility, focus for attention, impulse control, delayed gratification and accepting consequences” (p. 442).

Hallam (2010) explains that while the majority of research in music education is related to intellectual development and attainment, there are several studies that suggest an apparent influence of music curriculum upon child social development. 
For instance, some positive social outcomes in children and youth attributed to the practice of music are: the increase of self-esteem and self-efficacy, the facilitating of self-expression, the development of interpersonal skills, better social adjustment and more positive attitudes, the enforcement of discipline, the strengthening of perseverance, conflict resolution skills, and the promotion of active participation in different social environments (Arts Education Partnership, 2012; Gooding, 2011; Hallam, 2010; Hewitt and Allan, 2012; National Assembly of State Arts Agencies, 2006).

During the last ten years, largely influential social outcomes have been attributed to programs inspired by the Venezuelan musical program, called El Sistema. The Venezuelan system of orchestras and choirs is a seminal project that seeks to encourage, by employing intense musical training, the development of social awareness, citizenship, and an aesthetic sense of life for children and youth (El Sistema USA, 2014; Uy, 2012).

\section{Group Learning and the El Sistema Model}

El Sistema is a musical program that started in Venezuela and, during the last decade, has been replicated globally. The program’s aims include the human development and social organization of its members through individual and collective musical practice in orchestras and choirs (Fundación Simón Bolívar, 2014, para.1). Monascal (2006) explains that El Sistema name comes from an abbreviation of The Venezuelan National System of Youth and Children’s Orchestras. Jose Antonio Abreu founded this program in 1975. Four years later, the Venezuelan state ensured continuing unconditional support to this system of orchestras and choirs, regardless of the government in power, by establishing its existence through official process of law (Fundación Simón Bolívar, 2014, Historia, para. 6). At this time, El Sistema is funded 
by different sources, the Venezuelan Government and the Inter-American

Development Bank, being the two most significant (Menoscal, 2006).

During the life of this music program, a vast number of international

organizations have awarded and recognized different aspects of this project. In 1998, The Organization of American States (OAS) promoted "El Sistema” as a model of community education. Likewise, UNESCO in 1995 created the World System of Youth Orchestras and Choirs in order to promote world peace through the music performance (Sanchez, 2007). The stated goal of this organization is to democratize music education, making it accessible to all children, especially those with limited resources. Menoscal (2006) defines El Sistema as:

An organization that contributes to the pedagogical and ethical rescue of the childhood and youth, by means of the instruction and the collective practice of music, as well as the qualification of young craftsmen in the manufacture and repair of musical instruments. (p. 15)

Followers of El Sistema believe that orchestras and choirs are more than just artistic structures. These musical ensembles are fertile fields for the fostering of, “aptitudes, attitudes, and ethic, aesthetic, and spiritual values” (Borzachinni, 2010, p. 96). Seeking such social goals, El Sistema has developed itself by adopting and encompassing distinctive features that distinguish it from traditional musical instruction observed in most conservatories and music academies.

Foundations of El Sistema. El Sistema philosophy is grounded on the belief that music is an agent of social change. According to UNICEF (2014) social change "is understood as a process of transformation in the way society is organized, within social and political institutions, and in the distribution of power within those institutions” (Communication and Development, para. 2). The Simón Bolívar Foundation (2014) states that El Sistema’s mission is “the pedagogical, occupational 
and ethical rescue of children and youth living in socio-economically vulnerable groups” [own translation] (Fundación Simón Bolívar, Misión y Visión, para. 1). This rescue may be achieved by offering a new perspective of life through the collective practice of music (Fundación Simón Bolívar, Misión-y-visión, para. 1).

Erich Both (2012) states that El Sistema "is a social change/youth development program that uses ensemble music to enable every child to experience being an asset within her or his community, inside and outside the nucleo [see explanation below about nucleos]... developing not just musicians, but also responsible citizens (para. 10). Achieving the social goals of El Sistema necessitates an ongoing struggle against many adversities. This is why the most important motto in El Sistema is “fight and play” [own translation]. Hollinger (2007) explains that this phrase is referring "not so much a call to action as a change in mind-set” (p. 1).

Borzacchini (2010) points out seven premises conceived by Abreu that underpin the philosophic body of El Sistema: 1) The enjoyment and learning as social right, 2) The capacity formation, rehabilitation and social insertion, 3) The integration of individual with the family and community, 4) material poverty defeated by spiritual richness, 5) music embedded in everyday life, 6) overcoming false musical paradigms, and 7) paths for meritocracy and country development.

El Sistema's curriculum. Freddy Sanchez (2007) suggests that this program has been successful because the philosophic beliefs (explained above) and the subsequent curriculum developed and then implemented were in close synergy. In this regard, Abreu articulates that the pedagogical essence of El Sistema is the "intensive collective practice combined with the engagement of maintaining life through the enjoyment of making music” [Own Translation] (Borzachinni, 2010, p. 141). In Venezuela there is a national curriculum that is applied to every orchestra in different 
musical centers called "nucleos.” Yet "local leaders can customize their programs” that, if applied, could be adopted by other programs (Sistema England, 2014, para. 22; El Sistema USA, 2014).

The life in El Sistema's curriculum incorporates various stages of learning and performing. The first stage is initiated when children between the ages of two and five years old are sensitized to music by involving the children in musical activities connecting body expressiveness and rhythm. The second phase is called "musical induction.” A during which time a five year old child is first introduced to a choir experience, and also picks up a first percussion instrument or recorder. Next, children six to eight years of age are introduced to the art of instrumental performance. In this stage, children may pick up their first wind or string instrument and take part in a variety of musical ensembles ranging from sectionals to the big orchestra (see Borzachinni, 2010; Menoscal, 2006; Fundación Simón Bolívar, 2013). Between 15 and 22 years old, children and youth play in different orchestras, depending on the musical abilities developed during their musical instruction (Menoscal, 2006). Over the course of time, the students have different musical experiences, including public performances, private lessons, and communal classes.

Different arrangements of classical masterpieces underpin the Venezuelan system's curriculum. The program begins with the performance of simple scores and progresses to more complex classical music that expresses a larger sound, such as Beethoven's $5^{\text {th }}$ Symphony. This music is then reintroduced during different stages of the student’s music instruction (Fundación Simón Bolívar, 2013). The quality of the musical performances as well as the level of the musical repertoire of Youth orchestras is dramatically increased, resembling more of what is seen in professional orchestras (Menoscal, 2005). 
Furthermore, the public performance of the music mentioned above is vital to the achievement of the system's goals. As it is mentioned on the Venezuelan system websites, "students play in front of audiences as much as possible" in order to control the pressure of a formal performance and acquire a more natural conduct when the time comes to play in public. (Fundación Simón Bolívar, 2013).

Different benefits are attributed to El Sistema’s methodology. Menoscal (2006) lists various positive developments in the character and natures of students that are fostered through the Venezuelan system's curriculum; an increase in confidence levels in children and youth, the ability to appreciate the aesthetic in more complex terms, a team work mentality, the willingness to strive for excellence, the development of leadership qualities, determination, self-worth, discipline, problemsolving skills, perseverance, cooperation and coexistence, competitive spirit.. Likewise, societal benefits among family, community, and nation have been credited to this program. Tricia Tunstall (2012) depicts several El Sistema experiences in her "Changing Lives” book. She mentions experiences of one of the most important icons of the contemporary classical music, Gustavo Dudamel. Dudamel emerged from the system in Venezuela and has been part of the program's development in many countries. Currently, the director of the Los Angeles Philharmonic, Dudamel is involved in healing communities in Los Angeles and many other musical centers throughout the world.

The El Sistema's experience. Many countries around the world have embraced the El Sistema experience. For instance, during the last ten years United States educators have the Venezuelan system throughout the country. In 2013, The National Alliance of El Sistema Inspired Programs (NAESIP) was organized in order to provide support and advocacy for people and organizations inspired by Venezuela's 
monumental music education program” (El Sistema USA, 2013, para.3). This alliance includes more than 40 organizations working in twenty-seven states in the United States and Puerto Rico (El Sistema USA, 2013). Shoemaker (2012) exposes the experience of El Sistema in the Orchkids orchestra, which belongs to the Baltimore Symphony Orchestra. The author explains how this orchestra and the Venezuelan orchestras converge with the aim of transforming the reality of its members through the music, particularly since both of them are working with "at-risk" youth in what might be considered “dangerous” neighborhoods. Orchkids has adopted its educative structure from Venezuela, using classical music at the center of its curriculum. A difference between these orchestras is that while the government broadly finances El Sistema in Venezuela, Orchkids is privately funded and associated with the Baltimore Symphony (Shoemaker, 2012).

As a part of the implementation process of El Sistema in The United States, Jose Manuel Abreu and the conservatory of New England created the Abreu fellowship program, which is define below:

The Sistema Fellows Program is a professional training program designed for ten postgraduate musicians and music educators who are passionate about creating careers for themselves that connect music, youth, and social change. Past participants in the Program have gone on to guide the development of numerous El Sistema-inspired programs across the United States and beyond. (New England Conservatory, 2012, sistema-fellowship-curriculum, para. 2)

A. Rodas, a graduate of this program, explains that El Sistema Fellows program is a compilation and representation of the Venezuelans' experiences during the last thirty years. Likewise, he stresses the fact that El Sistema is not a rigid methodology, but instead, it is an open source where teachers should adapt to the conditions of the setting and people (A. Rodas, Personal communication, November 16, 2012). 
Furthermore, S. Siman, a teacher in the Abreu Fellowship program and codesigner of El Sistema in Miami, states that although there exists implied differences among Venezuela's system and other orchestras around the world following this model, classical music is the foundation of El Sistema curriculum. According to Siman (2012) this music represents the only way in which the young musicians could achieve the excellence (S. Siman, personal communication, November 15, 2012).

Documented experiences are available to music educators showing the influence of participation in musical ensembles based on El Sistema philosophy and how they affect the development of children’s social relations. One example is Big Noise Orchestra of Scotland, a project that “aims to use music making to foster confidence, teamwork, pride and aspiration in children taking part —and across the wider community” (Big Noise, 2014). In 2011 The Scottish Government led evaluation of the project articulates that "families report improved relationships at home, wider social networks and more shared activities between parents and children” (p. 38). While the outcomes of this project are centered in the milieu of the orchestra's members, the prediction of the long-term outcomes is risky due to the programs' newness. Regardless, as in other manifestations of programs that are surrogates of the Venezuelan El Sistema, there exists a strong belief that Big Noise has a positive influence on the future of its members-even if supported by personal and communal felt estimations. For example, the Big Noise project community believes that the likelihood of criminal and anti-social activity will be reduced and therefore they expect an improved social cohesion and a more employable population in this area (GEN, 2011, p. 42). Furthermore, this document claims how Big Noise project has contributed to national policy outcomes: giving children a good start with the Big Noise early intervention in nursery and elementary school; building National 
pride; fostering successful learners and responsible citizens; improving the education; developing a society safe from crime, disorder and danger; better resilient and supportive communities; healthier citizens; decreasing of significant inequalities in Scottish society (GEN, 2011).

Likewise, it is known that there are many other projects also operating on the foundations of the Venezuelan system of youth choirs and orchestras, as can be seen on the official website that articulates "El Sistema as a unique program, worthy of being implemented in all the world's nations, particularly in countries that are seeking to reduce the levels of poverty, illiteracy, and exclusion among young population” (Fundación Simón Bolívar, 2014, para. 1). In fact, El Sistema’s curriculum and methodology have been resembled by many musical projects in different countries such as Argentina, Australia, Austria, Brazil, Costa Rica, England, Italy, Jamaica, India, Scotland, South Korea, United States, and Guatemala among others (Fundación Simón Bolívar, 2014).

Critiques to El Sistema. In 1975, a small group of eleven musicians organized El Sistema. Forty years later, the Venezuelan system embraces more than 300,000 children and youth studying in nucleos developed in every state. This musical project was funded through its history by different Venezuelan governments, international institutions, and private enterprises (Fundación Simón Bolívar, 2014; Sanchez, 2007; Uy, 2012). Anyone looking at the Venezuela System will notice a dichotomy between the portraits established by the media, which highlights the benefits of these types of programs on the development of children and youth, and the critiques labeled by musicians, politicians, and journalists. These critiques focus mostly on three topics: the possible political ting of El Sistema in Venezuela; the alienation and cultural deference levied by western classical culture; and the lack of data and investigation 
providing clear evidence of the educational and cultural benefits resulting from the El Sistema, its practice and philosophy (Caznok, 2013; Dorantes, 2014; Goodman, 2014; Marshall, 2014; Toronyi-lalic, 2012; Sandow, 2014).

Firstly, during last five years, the Venezuelan System has been criticized for serving the personal political goals of Hugo Chavez and Nicolas Maduro, expresident and current president of Venezuela, respectively (Dorantes, 2014; Montero, 2014). Majno (2012) says that one symptom of this association is the "renaming of FESNOJIV as Fundación Musical Simón Bolívar” in 2011, which was directly financially dependent on the president's office (p. 60). It is interesting to note that the Fundación Simón Bolívar website (2014) explains that El Sistema is a musical program that has operated along ten different Venezuelan governments since its inception, but without any formal political party affiliation. El Sistema is a public institution, open to everyone in the country, and designed to facilitate and manage different agreements between itself and multiple organizations, the government among them (Fundación Simón Bolívar, 2014, Historia, para. 9).

Secondly, El Sistema has been characterized and praised for its commitment to social change through musical excellence, specifically, at a time when the sole focus was on classical music (Fundación Simón Bolívar, 2014, el-sistema, para. 2; Ibarim Brizuela, personal communication, February 22, 2014). Various authors expressed concerns about classical orchestras becoming last goal of music, and thus the promotion of European ideals in ways that suppress and repress the identity of other kinds of cultural music expressions (Caznok, 2013; Day, 2013; Green, 2003, 2006; Gaztambide-Fernández, 2008; Midgette, 2012). Caznok (2013) explains that El Sistema portrays western traditional classical music as a symbol of "salvation of people” [Own translation] (p. 2) underestimating people’s autonomy and enforcing 
the feeling of a social order with a superior elite (European) to which we need to serve and bow. El Sistema activists have refuted such statements. They explain that this program includes different types of music giving space for the manifestation of different identities. Eric Booth (2010) states:

Everyone "knows El Sistema is a classical music program; and yet, there is a lively presence of folk and popular music, even jazz appears in some places. Also, many new Latin American composers are composing hybrid music that defies category and fits with El Sistema processes. El Sistema is alive with music people love, that is the greater goal, and this makes it both a classical music program and, equally truthfully, a many-kinds-of-music program. (p. 5)

Since The Guatemala Municipal Orchestra was built and developed upon El Sistema tenets, the present study observes and evaluates how, if at all, the previously mentioned critiques apply to the Guatemalan case. 


\section{METHODOLOGY}

This study aims to discover the impact, if any, of the curriculum of the GMO upon the social interactions of its members. Given that a complex set of factors exists, and that it may and it does influence these interactions, this study explored the nature of said interactions within the context of a youth orchestra program.

The following questions frame this research:

- How do youth participating in the GMO perceive the curricular structure of the program and how it facilitates social interactions?

- How do teachers participating in the GMO perceive the curricular structure of the program and how it facilitates social interactions?

- How does the leadership of the GMO perceive the curricular structure of the program and how it facilitates social interactions?

\section{Rationale for Qualitative Designs}

The term qualitative research comprises numerous ways in which inquiry is pursued and developed in order to understand and clarify the meanings of specific social phenomena (Merriam, 1998). According to Amos (2002) there are many approaches that try to define qualitative research. They range from straight forward attempts such as "any kind of research that produces findings that are not arrived at by means of statistical procedures", to more specific definitions such as "a research paradigm which emphasizes inductive, interpretive methods applied to the everyday world which is seen as subjective and socially created” (p. 7). Creswell (2009) portrays qualitative research as a "means for exploring and understanding the meaning individuals or groups ascribe to a social or human problem” (p. 4). Despite the available definitional variance, different authors have attributed key characteristics to all qualitative design: natural settings, researcher as key instrument, 
multiples sources of data, inductive data analysis, participant's meanings, emergent design, theoretical lens, interpretation, and holistic account (Creswell, 2009; Marshall and Rossman, 1989; Merriam 1998, 1988; Saldaña, 2011).

There are different types of qualitative methods. Hancock, Dawson and Algozzine (2006) list the following approaches to qualitative research as most significant: Case study, ethnography, narrative, phenomenological studies, grounded theory, and biographical studies. These methods have differences, as they have developed from disciplines as varied as sociology, psychology, history and education among others (Hancock et al, 2006). Therefore, the selection of an appropriate method for the development of a research study is closely related and perhaps defined by the setting and particular features of each case in question (Creswell, 2009), as well as the questions raised by the investigation. Since the aim of this study is to explore and better understand the perceptions that parents, teachers, and children have about the curriculum of the Guatemalan Municipal Orchestra, a qualitative research approach was chosen to frame the inquiry.

\section{Case Study}

A case study was the qualitative design selected for the exploration of the GMO and its environment. Several authors have defined the case study as the most appropriate device for the exploration of a specific phenomenon bounded by clearly outlined characteristics (Guba and Lincon; 1981, Helmstadter; 1970; Woodside, 2010; Yin, 1994). Hancock et al (2006) explains that this method is based upon the premise of "conducting an empirical investigation of a contemporary phenomenon within its natural context using multiple sources of evidence” (p. 15). On the other hand, Merriam (1988) emphasizes four properties that are characteristic of case study designs: 1) Particularistic since it is based on a particular phenomenon; 2) 
Descriptive: this kind of research contains a rich description of the phenomenon; 3) Heuristic: case studies should facilitate to the reader understanding of the phenomenon in question; 4) Inductive: case studies provides the framework for the emergence of generalizations and concepts from the data.

This investigation was designed to meet the properties of qualitative case studies as described above. The study is bound to active members of the Guatemala Municipal Orchestra engaged in the Municipal School of Music (Particularistic). The research seeks to develop detailed and clear description of the GMO's environment in order to construct a comprehensive understanding of the case (Descriptive and Heuristic). Based on the data analysis and lastly, I formulated generalizations connected to the research questions (Inductive).

\section{The Role of the Researcher}

In this study, I was the only data collector. I have earned undergraduate degrees in Music Education and Forestal Engineering from the Universidad del Valle de Guatemala. In 2012, the Fulbright Institute granted me a scholarship that led me to the Master of Music Education degree at Florida International University. My main interest throughout the degree was to gain a better understanding of how to develop Guatemala's music education programs, particularly addressing processes that would foster social and cultural growth as well as social justice. I have taught in elementary and secondary schools and have also served as director and member of various choirs and musical ensembles. I am a composer and trumpet player for a well-known rock band that is highly visible in the Central America area.

I was also part of the first stage implementation of El Sistema in Guatemala, and since that time, I have established friendships with many teachers in the Guatemala Municipal School. Since I have traveled throughout the country and 
worked with individuals from different ages, social economic status, genre, and ethnicity, I am aware of the critical and often challenging aspects of the social reality of Guatemala.

Since a case study is a form of interpretative research that requires constant interaction between inquirer and participants, Creswell (2009) stresses the importance of considering ethical issues that could affect on bias the researcher as well as impact the integrity of the participants. In this investigation, much care was taken so that participants were provided an open and non-threatening environment, present in all the different stages of data collection. As a researcher, I obtained permission from the GMO's authorities evidencing that they were fully informed of all the steps and procedures involving the students, teachers, and staff at the Guatemalan Municipal Orchestra. Furthermore, in order to meet the high standards of human research that guaranty the participants’ integrity, I obtained permission from the Institutional Review Board (IRB) at FIU to complete all aspects of this research project (see Appendix).

\section{Setting}

The setting of this study was the Municipal School of Music, and more specifically the Guatemalan Municipal Orchestra, located in the civic center of Guatemala City. Currently, this musical center has more than 600 students from 5 to 18 years old, and finds itself under the administrative direction of Fernando Archila and Blanca López (Municipalidad de Guatemala, 2013).

According to the Guatemalan Municipal School of music’s website (2012), the Guatemalan Municipal Orchestra is the apex ensemble of this institution, which is comprised by more than nineteen musical groups, operating within six schools. The Municipal School of Music has been active since 2006 in the National Postal Office 
Building, located in the civic center of Guatemala City. Archila (2013) explains that the current members of this orchestra are advanced musicians who have excelled in other musical groups belonging to the Municipal school of music system (Archila, F., Skype Interview, September 23, 2013).

While the Guatemalan system of orchestral education has six distinct sites where different orchestras have been established, the GMO (Guatemalan Municipal Orchestra) was selected to be at the center of this investigation. The GMO is constituted by youth, all of who have experienced the Municipal School's curriculum for more than one year, and all of which show evident artistic development.

\section{Data Collection Procedures}

Several procedures and methods were used for data collection. Hatch (2002) explains that while quantitative methods use surveys, checklists, test, and scales to generate data, in most of qualitative inquiries the researcher is directly involved in the gathering of information. Indeed, several authors agree in identifying observation, interview, documents or unobtrusive data, as well as audio-visual materials as main methods to obtain data in qualitative research (Creswell, 2012; Lee, 1993; Marshal and Rossman, 1995; Merriam, 1988; Yin, 2003). In this study, the researcher used variants of these methods as a way to obtain and triangulate information.

Participant observation. Marshall and Rossman (1995) define Participant Observation as "a systematic noting and recording of events, behaviors, and artifacts in the social setting chosen for study” (p. 79). Observations and interviews are the major sources of information when doing case study research. The data obtained from these methods have a marked distinction from each other; while in participant observation researches are in charge of collecting evidence based on their appreciation of the participants, in interviews, the participants are the ones providing 
the information in their own words. Creswell (2009) points out some advantages of observation as a data collection method: the researcher has a first-hand experienceinformation; the researcher can record data as it occurs; uncommon aspects can be noticed through the process; it is an effective tool to examine uncomfortable themes to be discussed openly by participants.

One major concern when engaging in observations is defining what to observe. Merriam (1998) highlights six crucial elements to take in account when taking notes during observations: The physical setting, the participants, activities and interactions, conversations, subtle factors (informal activities, nonverbal communication, and what does not happen), and the researcher's own behavior (pp. 97-98). Based on this information and regarding the purpose of the research, observations may also help the researcher to choose candidates for future interviews (Saldaña, 2011).

The role of the observer can vary in different situations. In this study, I acted as “observer as participant”, interacting close enough with the GMO’s members without participating directly into their interactions and activities (Merriam, 1998, p. 101). Furthermore, I followed the observational protocol for note taking suggested by Creswell (2009), which includes descriptive notes and reflective notes. I observed one community concert and four days of the GMO normal activities, which include rehearsals, lessons, and recreational time. In order to further document said activities, I engaged in video recording, photographing, and note taking. Advance notice and consent was obtained from students, parents, and GMO’s staff (see appendix).

Interviews. Hatch (2002) defines qualitative interviews as "special kinds of conversation or speech events” that are used by researchers to explore informants (p. 
94). Although there are interviews involving more than two people, the most usual mode of interviewing is person-to-person (Merriam, 1998; Parker, 2011).

Regarding on how to formulate and introduce different questions, the interview can be approached in three different ways: 1) structured, when the wording and order of questions is predetermined, an oral form of written survey; 2) semistructured interview has a general design that includes a mixture of unplanned and planned questions; and 3) unstructured in which the questions are flexible and exploratory, it is more like a guided conversation (Merriam, 1998; Polkinghorne, 2005). The selection of interview type often depends on the nature of the study and the information sought by the researcher. For instance, if the researcher is looking to gather socio-demographic data, such as age, economic status, gender, level of formal education, a structured interview is more appropriated since the questions attend to specific responses based upon a common vocabulary. Another situation is when the researcher is not familiar enough with the phenomenon of the case. Under this circumstance, an unstructured interview would be more applicable as it contains more spontaneous open questions provoked by different topics arising from this guided conversation (Schuler, Farr, and Smith 1993; Packer, 2011; Merriam, 1998, Beck et al., 2004).

Qualitative researchers need and often use a less pre-configured and more open-ended type of interview, the semi-structured. In this interview format the researchers has a general plan about what topics and themes they want to cover; the questions, however, do not have a fixed order of appearance and may be modified during the development of the encounter, encouraging the interviewee "to speak in their own words to obtain first person account” (Packer, 2011, p. 43). 
Researchers must consider different elements in the elaboration of a semistructured interview. Griffee (2005) suggests five important issues to take into account with interview planning: defining whom to interview, location, identifying when to stop the inquiry, how data will be collected — recordings or notes — and which questions to ask. To stimulate responses from an informant, Merriam (1998) advises four categories of questions to be considered in the elaboration of a semistructured interview: hypothetical, devil's advocate, ideal position, and interpretative question. In addition, different authors recommend that one avoid multiple, leading, and Yes-or-No questions in order to have thoughtful information related to the purpose of the qualitative study (Merriam, 1999, Bogdan and Beaklen, 1992; Kvale and Brinkmann, 2009; Cassell and Symon, 2004).

In this study, I used personal semi-structured interviews with the academic director, musician members, teacher, parents, and the Municipal School of Music administrative manager. These interviews were developed using the components of Creswell's (2009) interview protocol: heading, instructions for the interviewer, the questions, probes for the questions, space between the questions, and a final thankyou statement (p.183).

Documents and unobtrusive data. Documents are a valuable source of information in case studies from which the researcher gathers data without interfering with participants or related events (Marshall et all, 1995; Yin, 2003). Diverse information gathered in this fashion is important as it provides “a behind-the-scenes look at institutional processes and how they came into being” and often "can give the researcher a sense of history related to context being studied” (Hatch, 2000, p. 117). The category of documents and unobtrusive data includes: public documents as newspapers, minutes of meetings, official reports, written reports, formal studies or 
evaluations, administrative papers or pamphlets, as well as private documents such as personal journals and emails (Creswell, 2009; Merriam 1988; Yin, 2003). Yin (2003) indicates the information coming from these sources is important to corroborate information from other sources-interviews, observations, and surveys-as well as means to verify correct spellings and titles or names of different organizations involved in the case.

Aiming to have a historical sense of the development of the Guatemalan Municipal Orchestra through its recent years and to confirm the information obtained during the data collection, I collected public and private documents related with the Municipal School of Music and The Guatemala Municipal Orchestra. The sources include three pamphlets, one different curriculum proposals, and several articles in local newspapers, and magazines.

Questionnaires. This strategy is a standardized format of data collection consisting of a series of questions aiming to find information linked to the research questions that frame the study (Marshall and Rossman, 1995; Borg, 1992). Questionnaires are a preferred strategy when the researcher wants to learn about the distribution of characteristics, attitudes, or beliefs from either a large number of subjects or people who cannot be easily interviewed (Marshall et al, 1995; Charles, 1998).

For the elaboration of questionnaires, Charles (1988) indicates two usual types of questions. First, “open-ended” questions eliciting written responses and explanations. Secondly, “force-choice” questions asking people to select one or more responses among different possibilities (p. 86). In order to obtain relevant and authentic information connected with a specific subject, effective questionnaires contain questions that are carefully elaborated. As in interviews, researchers should 
avoid asking "leading and multiple questions” (Merriam, 1998, p. 78). Yet, the use of yes-no propositions is normal in inquiries targeting the collection of factual information (Patten, 1998). Therefore, the information gathered by this kind of instrument ranges from sociodemographic data, used for statistics parameters in quantitative research, to qualitative specific information about personal experiences of respondents (deMarris and Lapan, 2004).

For this study, I used questionnaires containing open-ended and force-choice questions to inquire about personal experiences lived by musicians and parents into the GMO environment as well as factual information such as age, instrument, or gender.

\section{Coding}

In qualitative research, coding is the organization of raw data into themes, which in turn assist and frame the future analysis of the data (Mackey and Gass, 2012). Sabin-Baden and Howell (2013) explain that when researcher examine data they notice "things that stand out in the data set, such as behaviors, events, activities, strategies, states of mind, meanings, patterns, relationships, interactions or consequences” (p. 421). The aim of coding is to label these different things using nouns, adjectives, or adverbs to describe and capture the meaning of each data segments (Mackey and Gass, 2012; Cope, 2005; Corbin and Strauss, 1990; SabinBaden and Howell, 2013).

In this study I coded and organized the data in themes and sub-themes using what Corbin and Strauss (1999) call Axial Coding. In this type of coding, “categories are related to their sub-categories” making connections and relationships that are tested against data (Corbin and Strauss, 1990, p. 13). After decoding the data, I constructed a complex that describes the context and relationships among the themes 
and sub-themes in order to respond research questions, as well as to give a rich analysis of the case.

\section{Delimitation and Limitations}

This study is delimited to the youth musician members of GMO, their parents, and their teachers. Collection of field data was limited from November 15, 2013 to December 15, 2013. Likewise, documents and unobtrusive data were gathered between February 1, 2013 and December 15, 2013.

\section{Validity and Reliability}

The trustworthiness of research studies is determined by the parameter of validity. Merriam (1998) outlines validity in two categories. First, an internal validity that deals with "how the research findings match reality" (p. 201). Second, an external validity that is concerned with how the "findings of one study can be applied to other situations” (p. 207). In qualitative research, Creswell (2009) states that validity "is the accuracy of the findings by employing certain procedures” (p. 190). Different qualitative research literature suggests the following strategies in order to enhance the study's validity: triangulation, peer checking, long-term observation, member checks, participatory modes of research, and clarifying researcher's bias (Creswell, 2009; Merriam, 1998; Saldaña 2011, Swanborn, 2010; Yin, 2003). Many authors stress the weight of triangulation in giving validity to one’s data. Findings from different sources such as interviews, observations, and unobtrusive data give more accurate and reliable information than that based only on a few of these sources (Creswell 2009; Denzin et al, 2003; Hanckock, 2006).

In order to enhance the validity of this study, I triangulated information through different sources of information: interviews, field observations, and surveys from teachers, parents, and musicians. Moreover, I implemented other strategies 
suggested in the literature such as: confirming information with people involved in the GMO’s environment (Member Checks); sharing information with my advisors (peer examination); and revising my bias since I have had previous interactions with GMO’s members and leadership. 


\section{DISCUSSION}

\section{Conciertos de Barrio: Connecting Community with Classical Music}

It is 6:00 pm and over two hundred people are congregated in the community park of Zone 18, which is easily one of the most dangerous regions of Guatemala City. This city is the Capital of Guatemala, which is geographically divided in twentyone zones comprising approximately two million habitants. On one of the streets that are enclosing the park, a tarpaulin is covering an area in which the Guatemala Municipal Orchestra (GMO) is presenting one of its regular musical performances as part of the activities of the Municipality of Guatemala known as Conciertos de Barrio [Concerts of the Neighborhood]. The tarpaulin functions not just to protect the musicians and concert attendees from rain but also to isolate the noise coming from the street; this noise includes the laughter of many children playing in the park and the ordinary car traffic. The space seems inadequate for the amount of people trying to listen to the concert. Many are standing; there are no chairs to be had, which sends organizers scrambling, trying to accommodate more chairs and places for people to sit. At last, the master of ceremonies begins gesturing to the public and thanking the Municipality Mayor for the opportunity to bring this concert to this location.

In the midst of accolades and applause from the public and musicians' parents, the orchestra appears, dressed in black pants and distinctive white and green fluorescent jackets, the colors of the current Guatemalan municipal administration.

The program begins with the first movement of Beethoven’s Symphony No. 5 and then continues with a diverse repertoire that includes Italian arias, boleros, and Guatemalan music. This mix is traditional in all of the Conciertos de Barrio; they deliberately combine classical music with some popular songs of Guatemala and Latin America. During the concert, a drunk is walking and dancing to the music and 
singing along with the soloists. At first, people and musicians appear to be disgusted by his manners but soon everyone ignores him and even enjoys him, as if he were part of the performance.

The most celebrated part of the concert is the presentation of Luna de Xelaju, a song treasured by Guatemalans and considered their second national anthem. At this point, the conductor invites the Municipal Choir to the stage. The master of ceremonies announces that this will be the final selection of the evening, provoking a general sigh of disappointment in the audience. In the middle of Luna de Xelaju, the conductor turns and gestures to the audience, inviting everyone to join the chorus. People stand and sing. At the end of this emotional rendition, they remain standing and start yelling, “Otra, otra” [Encore, encore]. The conductor takes the microphone, praises the orchestra, and ends by thanking the public for their presence. Then, as he walks back to the podium, the master of ceremonies announces with great fanfare, “La orquesta va a tocar una pieza mas!” [The orchestra will play one more number] and again, giving thanks to the municipality of Guatemala and its mayor.

After the last song, which is another traditional Guatemalan song, the public stands once again and praises the musical ensemble with a loud and long applause accompanied by "Bravo", "Viva”. The conductor gestures to the public and invites the musicians to stand and bow, at which point the concert ends. The musicians abandon the stage conducting casual conversations with each other and playing one final passage of music. Little by little, the normal sound of traffic, people talking, children crying and yelling, and dogs barking returns, reigning once again over the environment that was filled with music just minutes ago. The concert is over.

Meanwhile, at the back of the stage, some orchestra members are talking about how the concert went: “¿Qué les pasó a las cuerdas en la segunda obra?” [What 
happened with the strings in the second piece?], “A pesar de que estaban un poco desafinadas nadie se dio cuenta " [Even though they were a little out of the tune, no one noticed that]. One violin player is wondering, quite loudly, if there are refreshments, but the principal trumpet player says that unfortunately, today there are none. The academic director praises the musicians for the performance, "Felicitaciones, todo salió muy bien. Sonaron increíbles. Gracias a todos” [Congratulations, everything went really well. You sounded wonderful. Thanks everyone]. Musicians, teachers and parents start to say goodbye to each other: "Que te vaya bien”, “Te miro el lunes,” “Todo salió bien, buenas noches” [Be well; See you on Monday; Everything went fine, have a good night]. Some orchestra members leave with their parents, while others board the two buses obstructing the traffic. It is 10:30 pm, the tarpaulin is taken down, the orchestra is parting, people in the neighborhood are walking home, and the lights dim. The Conciertos de Barrio is concluded.

\section{The GMO’s Headquarters}

The GMO has its headquarters in the 'Edificio de Correos' [National Mail Office]. This building is located in the midst of the Historic Center of Guatemala

City, and by the two most travelled avenues in the entire city, $7^{\text {th }}$ and $6^{\text {th }}$ Avenue. Two buildings connected by a bridge constitute the 'Edificio de Correos', which dates back to the 1940s, and declared part of The National Heritage by the Guatemala Government in 1981. Its eclectic architecture is representative of neocolonial nationalist style that contrasts with the modern and simplistic buildings around it. An array of businesses surrounds this historic building, ranging from restaurants, banks, and international company offices to street food carts, illegitimate cellphone accessory sales, and people exchanging currency without authorization of the central government. 
The building on the left continues to function as a post office, but also houses the Municipal School of music, dance, and graphic arts. This center has two entrances. The first is located in the front of the building and is used mostly by visitors of the school or people who are attending the post office. The second entrance is located in the back where the students, faculty, and administrative personnel enter. This building has three levels connected by a vertical shaft, or light well, which sheds natural light into almost every office and classroom.

The first floor encloses offices serving multiple functions related to cultural work of the Guatemalan Municipality. In the front of this floor, there is a staircase, one that represents a canonic example of neoclassical architecture. This staircase connects to the second floor. Located on the second floor are the administrative offices of the school of music, dance, and graphic arts. On this floor the atmosphere changes; the sounds of cars, buses and people selling on the street begins to be swallowed over by a combination of people singing, playing trumpets and strings, chatting, and repeating phrases such as: Un, dos, tres $y$, un dos tres $y$ [One, two, three, and, one....]; mas suave [more soft]; con delicadeza [gently], vamos otra vez, da capo [here we go again, da capo].

Walking along this floor, I see different classrooms with big windows that watch over the development of ballet and folkloric dance classes, painting lessons, and marimba and choir rehearsals. Different corridors connect the different classrooms, converging in a principal hallway. As I enter the hallway, adults and children are sitting on the floor pursuing different pastimes such as sewing, reading, doing homework, and talking to each other. When I ask them who they are and what they are doing there, most of these people respond that they are parents and siblings of youth and children involved in lessons and rehearsals at the Municipal School. 
Inside the building, there are several municipal police walking in hallways or standing in specific locations. Two of them explain that their duty is to guarantee the safety of the people attending the Municipal School. It is relevant that they have no firearms (which are typically used by police elsewhere in Guatemala due to the high index of violence) but rather batons and whistles in case something disturbs normal activities. Situated in the middle of the second floor is the Municipal School of Music office. This almost, too small office serves as headquarters for the academic director and the general director; there are two desks with some piles of papers. On the walls, there are many pictures and posters of different performances and events that illustrate the history of this School of Music.

Beside the main office, there is the faculty meeting room, a location where I conducted interviews. In both the faculty and director rooms, there is an invasion of sound coming from people practicing on the terrace of the third floor where the personal musical lessons of the municipal orchestra, choir, and band take place. Upon my arrival to the third floor, there is a grand open space, a type of terrace that has a light well running vertically through the middle. The view from this place is fascinating. It provides a view of the buildings and the area surrounding the historic center. On the terrace, there are special locations for each of the various activities. These locations include lesson rooms, rehearsing rooms, bathrooms, two offices, a general auditorium, a small theatre, and a large terrace.

Throughout the terrace, there are numerous children and youth practicing their instruments. On a wooden bench, eight children are playing different musical material assigned by teachers or ensemble conductors; they are either waiting for their individual lesson or practicing before orchestra, band, or choir rehearsal. At the end of the terrace, there is a sectional band rehearsal. Fifteen musicians play scales and 
chords as the trumpet teacher conducts them. Several children approach me and ask what I am doing there. I respond that I am observing. They are amicable, explaining to me the different activities at the school of music. The first activity they mention is instrumental lessons, located in the area situated beside the stairs. There are eight soundproof cubicles for these classes, all equipped with musical stands and mirrors.

On the right side of the general area, there are the bathrooms. Beside them is the entrance to the hall where concerts, recitals, and general rehearsal take place. This entrance hall is separated from the open area by a second light well that cuts through all floors similar to the principal light well, but is connected by a peculiar crystal bridge from where I can see people walking on the first floor. The auditorium is a space that has a wooden stage but without acoustic treatment, contributing to a natural echo effect.

At the end of the open space there is 'el teatrino' [little theater], where most orchestra rehearsals occur. The GMO’s fifty-four current members occupy almost $90 \%$ of the room space, sitting in plastic chairs without armrests, except for the upright bass players who use special high chairs that facilitate their performance. The echo is considerably less than the auditorium, permitting a more discernable sound to resonate.

Close to the front and middle of el teatrino, there is a podium designated for the orchestra conductor. This large room would be very tight if there were ten more musicians. During my visit to the administrative office, I observe some pictures of past rehearsals of the GMO with more than one hundred people inside of this room, and it looks very crowded. The sound of people rehearsing with a variety of instruments at the terrace — the marching band and individuals practicing — enters through the door and windows, making it a little difficult to hear the conductor. 


\section{Evolution of the GMO: The Beginnings, Crisis, and Rebirth.}

Although the GMO started official activities in 2006, its origins date from one decade before. In the 1990s, Guatemala had only one conservatory and a very limited number of music academies endeavored to provide instruction in both classical and popular music. At the beginning of 1997, a group of musicians from El Sistema ${ }^{1}$, [the System of Youth Orchestras and Choirs in Venezuela], organized an intensive seminar in Guatemala City. This seminar brought together more than one hundred Guatemalan musicians who received individual and collective lessons throughout the week. At the end of the seminar, there was a final performance including, among others, musical works of Beethoven and Mozart. This experience resonated among different musical circles of Guatemala's society, sowing the idea of organizing a new large orchestra. In 1998, La Fundación Musica y Juventud [Music and Youth Foundation] started a project that promoted the connection and creation of orchestras, choirs, and bands throughout the country. In 2006, the mayor of Guatemala City, along with members of Fundación Musica y Juventud, funded the Guatemalan Municipal School of Music ${ }^{2}$ whose first and more prominent ensemble is the GMO.

During its history, the GMO has gone through different administrative phases and political stages. The beginning of the program followed the tenets of El Sistema, especially social change as the ultimate goal, the music instruction through the performance of classical masterpieces, and the idea of nucleos [nuclei] as centers of music development. During the first five years, and under the wing of El Sistema, the Guatemalan Municipal School of Music attended to more than two thousand children

\footnotetext{
${ }^{1}$ In this study, El sistema refers just to the Venezuelan program unless exist a clarification such as El Sistema USA or El Sistema Scotland.

${ }^{2}$ It is important to clarify the difference between the Guatemalan Municipal School of Music and the Guatemala Municipal Orchestra (GMO): While the first is the network of different nucleos and ensembles, the later is the orchestra more prominent of this network.
} 
through activities in six nucleos and fifty musical ensembles, the most prominent being the Guatemala Municipal Orchestra (GMO). Around this time, the administrative director at the time and some students were traveling to Venezuela, not just to receive musical training, but also to live and internalize the El Sistema philosophy.

In a midst of accolades from many public segments, the raising of new nucleos, and the enlargement of previous musical centers, The Municipal School of Music faced an administrative crisis that affected its evolution and organization. While it is not clear what exactly happened during this time, most of the current faculty and administrative personnel expressed their discomfort with the 2010 and 2011 administration and their bad practices in the management of financials and pedagogical practices. Even though an official record does not exist, it is rumored that that these disconformities provoked the sudden quitting of the then administrative director who was one of the founder of the project and also the musical conductor of GMO at that time. The aftermath of this crisis was a schism between people supporting this administrative director and those who disagreed with his procedures. This situation was the impetus for the creation of a new institution, El Sistema de Orquestas de Guatemala SOG [The Guatemala System of Orchestras] that works independently from the current the GMO.

After this division, The Municipal School has been fine-tuning its reorganization. The current administration admits, that even though they are following some of the fundamentals of El Sistema, during the last three years the institution has been working on the development of its own curricular identity and plan. Currently, besides taking their individual instrumental lesson and ensembles, students are taking formal courses in music theory, history, and conducting. This formal coursework 
gives the students other opportunities in addition to just intensive ensemble training. Another reason for this innovation is to fulfill official requirements by the Education Minister that permit the issuance of formal certificates of education, as recognized by the government. The academic director mentions that with this extended formal education, the school aims not just to give the constancy of a large musical training, but also to facilitate the transition of these new musicians into formal business, specifically as teachers, instrumentalists, or administrative personnel.

The GMO's current organization. The GMO is the highest point in the hierarchy of the Municipal School's ensembles. The selection of its members is done through a process based on hard work and persistence; the GMO’s members are not just the more advanced musicians belonging to six different nucleos, but also musicians that demonstrate high levels of responsibility in their performance and attendance to the GMO rehearsals and concerts. In every concert they use a distinctive uniform with the official colors of Guatemala City Municipality, green and white. Other concerts are seasonal, including special programs during certain times of the year such as Christmas. Their programs also include several invitations to play in different locations.

The GMO’s curricular structure is the responsibility of the administrative director, the academic director, and the principal conductor. Together, they choose repertoire and schedule lessons, rehearsals, and concerts. During observations and interviews, I noticed the lack of an explicit curriculum for the GMO. The academic director told me that when the orchestra first started, they tried to replicate El Sistema model, which is based on the study of famous works from western traditional music. This replication never included an official curriculum. He continues saying that since one year ago they are working in the development of an official curriculum proposal 
according to the Guatemalan context. This proposal is a referential framework for the whole Municipal School of music without specific guidelines for the development of the GMO. However, when I spoke with teachers, they told me that today they select and organize content and methodologies according to what they think is necessary for students’ development and learning within the GMO activities.

\section{GMO’s Funding}

Looking at different sources of different media, such as the archives of the GMO, the Internet, the National Library, and consulting with renowned cultural journalists in Guatemala, it is clear that there is an abundance of media related to the GMO. The majority of articles have praised the musicality of the orchestra stressing that even though the members are young they are playing difficult repertoire at a professional level. Most public opinion highlights and claims the social value of this orchestra for the Guatemalan society, as it may potentially help reduce or prevent the high levels of poverty, violence, and delinquency that many members could fall victims to. These attributes motivate different sponsors for the expansion and strengthening the GMO by funding new nucleos, acquiring more and better instruments, implementing scholarships, and offering diverse workshops in instrumental performance and lutherie. The array of organizations that have supported the program includes USAID, the embassies of Israel, Italy, and France, as well private institutions.

The normal activities for current GMO members run Monday to Friday, beginning at 2:30pm and finishing around 6:30pm. Every member of the orchestra plays three different musical roles in the development of the GMO activities. First, they are musicians and artists comprising the musical body of the GMO for rehearsals and concerts. Second, they are students that receive classical musical instruction. And 
lastly, they are a talleristas [teacher assistants] that are charged to assist different instrumental professors in the development and reinforcement of individual lessons.

Although this an official schedule, many of the students tell me that sometimes they need to stay after 6:30pm, and this is either because the orchestra needs more time to prepare new material or there are concerts at night or during the weekend. Ismael explains to me that although the municipality gives them transportation to and from the school to where the concerts take place, there is no transportation to and from individual homes if it is late at night. However, at the conclusion of a typical day, activities wind down around 6:30pm. During this time, the terrace is dark and the sound of instruments starts to disappear dominated by the sound of the peak hour traffic invading the installations of the school.

\section{Summary}

This chapter is a description of the history and structure of the Guatemalan Municipal Orchestra (GMO). Since 2006, this orchestra has been the highest point in the hierarchy of the system of choirs, bands, and orchestras belonging to the Municipal School of Music. This school is located in the historic center of Guatemala City and is principally funded by the Municipality of Guatemala and other private organizations. The fundamentals of the School of Music were initially underpinned on the philosophy and tenets of El Sistema in Venezuela. At this time, the school is following a distinct curricular and structural pathway based on the local experiences lived during the last eight years.

At the School of Music, the life of the GMO’s members are immersed in an intense set of activities of work, study, and performance from 2:30 to 6:30, from Monday to Friday; frequently, they need to stay longer or attend during weekends or holidays for special events, such as concerts or extra-rehearsals. Their principal 
responsibilities include: the attendance to GMO concerts and rehearsals; the study of the courses on musical theory, history as well as the instrumental lessons and ensemble practices (chamber music, choir and band); assisting teachers in the supervision and reinforcement of students in the beginning and intermediate levels. 


\section{DATA ANALYSIS}

This study examines the influence of the Guatemalan Municipal Orchestra Curriculum on the social interactions of its members. The researcher organized data into different themes and subthemes through the process of Axial Coding. Two major themes emerged from such process. The first is Sense of Community, where notions such as student's sense of belonging and the bidirectional influence between students and the GMO as institution are included. The second is Motivation, comprising the students' intrinsic motivation and external motivators as they relate to the GMO experience. In this chapter the researcher makes conceptual connections within themes and existing literature review through the lens of Participatory Literacy.

\section{Sense of Community}

The Municipal School of Music is a place where several/different aspects of the GMO members’ lives converge. From Monday to Friday students spend more than 25 hours coexisting with other youth and children, as well with teachers and visitors. In several interviews students refer to the school as their second home and the orchestra as a special family to which they belong. This is apparent in the two statements below:

Aquí aprendí que todos somo iguales, no importa de donde vengas.... Aprendí que somos una familia [I learned that here everyone is equal and it does not matter where you are coming from-referring to economic status. Here, I learned that we are a family] (Student).

Nosotros somos como una familia en donde nos cuidamos, nos regañamos, reimos y lloramos [We are as a family where we take care of each other, admonish each other, laugh and cry together] (Student).

These statements suggest the existence of a sense of community. According to Gusfield (1975), community is a term with two major uses: The first is definitional and related to the "geographical notion of community-neighborhood, town, or city", 
and second, is relational "regarding the quality of character of human relationship, without reference to location" (McMillan et al., 1986, p. 3). The current investigation revealed that the GMO’s headquarter is perceived by student as a community, functioning both as the geographical space for musical development and the relational environment for social interaction.

Focusing on human relationships, McMillan (1976) defines a sense of community as "a feeling that members have of belonging and being important to each other, and a shared faith that members' needs will be met by the commitment to be together” (in Chipuer and Pretty, 1999, p. 646). McMillan identifies four important elements in the development of the sense of community: membership and sense of belonging, influence, integration and fulfillment of needs, and shared emotional connections. The data from the present study provides evidence of the existence of a sense of belonging, one that influences the overall community of learning at GMO and is made manifest in several ways, including those presented below.

Sense of belonging and membership. Hagerty et al. (1992) define sense of belonging "as the experience of personal involvement in a system or environment so that persons feel themselves to be an integral part of that system or environment” (p. 172). In several interviews students referred to their participation in the orchestra as “we”, suggesting they view GMO as a unit. This is evident in the following students' testimonials:

Nosotros a la hora de tocar somos uno solo [When we play, we are just one] (Student Interview).

En cada concierto nosotros queremos demostrale a Guate de lo que estamos hecho [In every concert we want to demonstrate to Guate - Guatemalawhat we are made of] (Student Interview). 
McMillan (1986) states that Membership is part of the sense of belonging and can be understood as the "feeling that one has invested part of oneself to become a member and therefore has a right to belong” (p. 5).

While participation is active, the GMO membership is nevertheless controlled: externally, by academic and administrative personal of the Municipal School of Music; and internally, regarding the personal commitment from every student to the institution. Teachers and administrative personal at the Municipal School of Music established the requisites for GMO’s membership, and as the guest conductor explains, it is not easy to be part of the orchestra given that every one needs to have discipline and responsibility toward the music and the institution. Students are required to pass an exam that assesses their abilities as musicians ability and when accepted they are required to attend and succeed in different music theory, harmony, history, and sigh-singing courses.

The membership established by the Municipal School of Music is complemented by the internal commitment of GMO members to the institution. Students demonstrate strong awareness that they need to study and maintain a certain level of playing in order to become and remain part of this orchestra. Jose, a bassoon player shared his personal experience:

Para estar aquí tuve que estudiar mucho y pasar un examen, tuve que tocar enfrente de mis profesores varios estudios de fagote y partes de orquesta. Pasé, pero igual tengo que estudiar todos los días para mantener mi posición en la sección.Es duro pero vale la pena [To be part of the orchestra I had to study a lot and I had to play alone basson's orchestra excerpts in front of my professors. I passed but regardless I need to study constantly if I want to keep my position. It is hard, but worthy] (Student).

This personal commitment is extended to a collective commitment, that is, to the community to which they belong. Parker (2010) states, "In music ensembles, the belonging that one experiences results in the desire to interact and participate in 
music-making with others” (p. 11). In both surveys and interviews, various members of GMO expressed connectedness with other orchestra members during rehearsals, concerts, and other activities.

Esta es mi segunda casa, aqui paso la mayoría del tiempo tocando y haciendo lo que me gusta con mis amigos. En mi casa casi no hago nada [This is my second home. Here, I spent most of the time playing and doing what I like with my friends. In my house [referring where she actually lives] I hardly do anything] (Student interview).

Nosotros somos una famila y compartimos muchas cosas personales aparte de la música. Aunque a veces nos peleamos nos queremos mucho [We are a family and we share many things besides the music; even if sometimes we fight, we love each other] (Student interview)

McMillan (1986) argues that a "sense of belonging and identification involves the feeling, belief, and expectation that one fits in the group and has a place there, a feeling of acceptance by the group, and a willingness to sacrifice for the group” (p. 6). This identification may be represented in statements such as "I'm part of the group" or "this is my group" (p. 6). GMO members made similar declarations:

Esta es mi segunda casa [This is my second house]. (Student survey)

Mi familia dice que soy parte de algo importante [My family says that I am part of something important]. (Student survey)

Nosotros hemos tenido importantes conciertos [We have had many memorable concerts]. (Student survey)

A veces [nosotros] sonamos mal pero siempre damos lo mejor [sometimes we sound not so good, but every time we try to do our best]. (Student Survey)

Analysis of the data shows that the GMO is a key geographical space where members experience a relational sense of community. As we see below, it is also evident that managing a multi-faceted set of roles_-as musicians, students, and teacher assistants — facilitates and indeed nurtures their sense of belonging to the GMO. 
Influence. McMillan (1986) explains, “influence” as a bidirectional concept, where for an individual "to be attracted to a group, he or she must have some influence over what the group does. On the other hand, cohesiveness is contingent upon a group's ability to influence its members” (p. 6). Data suggests the existence of different levels of influence of the GMO on their members' lives: First, the influence of the GMO in the development of soft skills; then, the influence among the GMO members through the collective self-monitoring; and finally, the influence of students on the GMO community and structure.

Influence inside of the GMO community. The first apparent level of influence pertains to the impact of GMO's curriculum on the hard and soft skills' of its members. Hard skills are the technical, cognitive, and technological abilities displayed through successful performance of a specific task (Ellis, Kisling, and Hackworth, 2014). The GMO maintains certain standards of practice focused on students’ playing technique and music theory skills, and these result in student preparedness toward musical performances (Field observations). While it is easy to define and measure hard skills, the delineation of soft skills is more complex, once it depends on contextual factors. Typically, soft skills are those related with the acquisition and development of personal social traits, interpersonal skills, and problem-solving (Rao, 2012; Schulz, 2008; Shakir, 2009).

The orchestra members are actively immersed in multiple activities that require the use of hard—musical skills. Participation in these activities and the environment that surrounds and delineates them creates a process of enculturation, which also requires soft social skills. This enculturation through musical immersion may be impactful for the development of students' soft skills. For example, taking an individual class once a week; assisting instrumental teachers with beginners; 
rehearsing with the orchestra three times per week; attending all the concerts, all these activities require punctuality and self-discipline. They also provide multiple ways to behave, to interact with others, and to construct one's understanding of what is appropriate, desired, expected within the community. There is evidence that the intensive immersion of the GMO members in this environment enhances their development of soft skills. Morrow (1994) explains that being responsible "involves being accountable, answerable, capable, competent, dependable, reliable, trust worthy and so on” (p. 132). Students identified discipline and responsibility as characteristics learned and fostered by their performance in multiple activities at GMO, as two students affirm:

Yo aprendo, disciplina, respeto y responsabilidad [I learn [at GMO] discipline, respect and responsibility]. Aprendo a ser disciplinado y a concentrarme" [I learn to be disciplined and to be focused]. Aprendo a concentrarme en lo que me gusta y a ser respetuoso con la opinión de los demás aunque a veces no piense lo mismo [I learn to be focused in what I like and also to be respectful with the opinions of others even if I do not agree]. (Student interview)

A veces mi mama me dice que me ve cansada y me pregunta que si no prefiero quedarme en la casa, pero yo le digo que mis compañeros me necesitan, es mi responsabilidad [Sometimes my mother thinks that I am tired and asks me if I would prefer to stay home instead of going to rehearsals; I say that I need to go because my mates need me, it is my responsibility]. (Student interview)

Two parents explained that indeed, GMO plays a role in how their children experience and learn responsibility:

Los ensayos y los conciertos son algo sagrado para él, no le gusta faltar y no le gusta que lo regañen [For him, the rehearsals and concerts are something sacrate. He does not like to be absent, and he does not like to be admonished] (Parent interview).

Yo no tengo que decirle que estudie su instrumento, él solito se mete horas a estudiar su violin [Without prompt, he spends hours practicing the violin] (Parent interview). 
A few parents also reported improvement in their children's personal traits outside of the GMO environment, a fact that they attribute to participation in the GMO activities. For instance:

Mi hijo es inquieto y se desespera rápido, pero ahora creo que sabe controlarse mejor... tiene mejor disciplina al menos eso me han dicho en el colegio [My son is restless and used to become very anxious very easily, but now I think he knows to control himself. He has more discipline, teachers at school said that] (Parent Interview).

Aunque a él prefiere tocar a hacer las tareas del colegio, hace el esfuerzo por terminarlas. Creo que ahora es más responsable [Although he prefers to play music rather than do homework — regular school— he puts some effort to finish it. I think he is more responsible now]. (Parent interview)

Yo si he notado un cambio de actitud en él, es más educado con las personas en la iglesia [I have noticed an attitude change, he has better personal skills with people in the church]. (Parent interview)

Based on the data presented above, it is apparent that the environment established by the GMO enhances such soft skills, it is difficult to know with certainty, however, the extent of GMO' impact as it is not the sole influence on these developments.

Collective and self-monitoring. The data suggest students' self-monitoring behavior by the students during participation in different activities of the GMO. Selfmonitoring involves the observation and identification of "the presence, absence, or level of a specific behavior” (Simonsen, Ashley, MacSuga, Lindsay, and Sugai, 2012, p. 6). Serafin (2012) explicates that self-monitoring is the starting point for a behavior change process known as self-management. Self-management was clear in my observations, so much so that often when the conductor would ask students to be quiet they acquiesced immediately. In several situations student musicians would "shhh!" others in the group, requesting silence. At other times musicians addressed their peers in a direct verbal manner. In all instances, the disruptive members responded to the 
requests, either speaking more softly or not all. This self and collective monitoring

was also suggested through many expressions of discomfort when other members

disrupted rehearsals:

A veces se nos va la onda y hablamos y molestamos cuando los profesores estan enseñando o dando instruciones a otro registro, pero cuando es mucho es cuando le decimos al que esta hablando cállate vos, el profe esta hablando [Sometimes we are not aware that we are talking while the teacher is giving instructions to other people. But when it is too much, that is the moment when someone says: hey close your mouth!!! The teacher is talking]. (Student interview)

Self-monitoring was also evident with regards to absences from rehearsals or

concerts:

Odio cuando alguien falta a los ensayos o a los conciertos porque no suena igual.... El director dice que es una falta de respeto y la verdad yo creo que sí.... es nuestra responsabilidad estar aquí [I hate when someone misses rehearsals or concerts; the conductors says that it is disrespectful and I think it is true. It [the rehearsals attendance] is our responsibility]. (Student survey)

Although it is not possible to determine if these behaviors are a direct product of participation in the GMO activities, numerous participants expressed an interest in similar issues, voluntarily. While students behave in these ways without prompt, data suggest several influences from GMO’s teachers. These can be organized or categorized in different ways, for instance, from a didactic stance:

Nosotros tratamos de enseñarles como comportarse como profesionales de la música, a ser serios con su trabajo y con sus compañeros [We teach them how to be professionals, that is to be serious with their job and peers] (Academic director interview).

Or from a more pedagogical standpoint,

Yo si creo que la formación de la orquesta influye en tu desarrollo personal.... empezas a enteder que no sos solo vos, que tenes que convivir y respetar a los demás.... Además te ayuda a saber como comportarte como profesional en cualquier circumstancia [I really think that the orchestra experience influences your personal development. You understand that it is not only about you, but that you need to coexist with others. Further, you learn how to behave as a professional anywhere] (Teacher interview) 
Regardless, these data suggest the GMO community exerts influence in the development of soft skills, such as discipline and responsibility, as well as selfmonitoring, self-management.

Member's influence on the GMO community. During the last two years the Municipal School and the GMO have experienced, and continue to experience, changes in its academic curriculum and institutional structure. According to the academic director, the opinions and experiences of students in the Guatemalan context have contributed to a shift in the GMO's curricular structure. Although the academic director says that they are not familiar with the tenets of Participatory Literacy, they have tried to include elements that are linked to the framework, taking particularly seriously students' input and their participation in the process of the reorganization of the Guatemala Municipal Orchestra. Jurmo (1989) affirms, "an active participation is when learners do more than simply show up for classes and do what they are told. To participate actively, they must take on higher degrees of control, responsibility, and reward vis-à-vis program activities” (p. 27). While it is uncertain the degree of student control on the GMO’s curricular changes, data point to student influence on two different aspects: the curricular expansion aiming towards the acquisition of a formal academic degree, and negotiations with new partnerships directed toward the sustainability of the project.

Curricular expansion: pursuing an academic degree. The original curriculum included a few basic music theory courses and was focused mostly in the orchestral practice. Currently, the academic committee is adding more theory courses as well as a variety of music ensembles such as chamber music and choral practice. According to the administrative director, "the principal goal of this new curriculum is to give an official degree certifying the musical studies of the GMO members” 
(Interview). During five years, parents, teachers, and students showed interest in obtaining such a degree, as evidenced below:

Nosotros queremos un programa más serio, con esto me refiero a hacerlo mas como obtención de títulos [We want a more serious program in the sense that I want a degree]. (Student Survey)

Nosotros nos preocupamos por el futuro de nuestros hijos, ellos necesitan un título para trabajar [We are concerned about the future of our children, they need a degree to be able to work]. (Parent survey)

Cuando salgamos de la escuela no vamos a tener un título y no vamos a conseguir trabajo facilmente, es porque eso que queremos un titulo para poder clases en colegio o academias [when we graduate from the school we will not have a degree and then we will not get a job easily. That is why we want the degree, to work teaching at schools or academies]. (Student survey)

Regarding these opinions, the administrative director articulates:

Los niños nos han enseñado y nos siguen enseñando que caminos seguir, hacia a donde ir" [Children have taught us which path to follow]. Ellos y sus papas nos han pedido que se les otorge un título que haga constar sus estudios musicales [they [children] and their parents have asked for a degree that evidences their musical studies] (Director Interview).

The academic director explained that at this time the school of music is giving a "diplomado" [diploma]. This title certifies that the student has finished their musical studies, but it holds not official recognition from the Guatemala Ministry of Education.

This process of negotiation for an official degree may be associated with Participatory Literacy's characteristics. Shor (2011) explains that one fundamental of this philosophy is to link education with learner's context and needs. The GMO students have made known their desired and perceived need for a degree, particularly as it may relate to employment, and the GMO administration has responded by including it in its recent curricular design. It remains unclear if this will remain a nominal process, or if credentialing — that has real world consequences—will be achieved in the future. 


\section{Motivation}

Given that the majority of the GMO members have participated for at least two years and retention is high, understanding what motivates them to keep playing in this ensemble is significant. This is also significant, particularly at the high school level where overall recidivism remains high. Beck (1978) affirms that motivation is a topic inherent in human beings "with the determinants of choice, persistence and vigor of goal-director behavior” (p. 24). Researchers have also analyzed the diverse intrinsic and external factors that affect motivation in children and youth (Basil, 2013; Denis and Jouvelot, 2005; Ryan and Deci, 2000; Sichivitsa, 2007; Sloboda, 1991). While intrinsic motivation "pushes us to act freely, on our own, for the sake of it” (p. 45), extrinsic motivation pulls us to act due to factors outside the activity itself, such as a reward or threat (Denis and Jouvelot, 2005). Furthermore, Sichivitsa (2007) identifies four principal external factors that influence the musical development in children and youth: parental influence, teacher influence, peer support, and previous experiences. The present research data exposes distinct indications of these motivators in the GMO members’ lives.

Parental support. It has been identified as one of the principal external motivators that stimulate students' persistence in their musical development (Anderson, Funk, Elliott and Smith, 2003; Hallam 2011; Hewitt and Allan, 2013; Sichivitsa, 2007). Hallam (2011) indicates that parents “can provide many kinds of support including guidance, financial and practical aid” (p. 268). In this study, several students point out the positive feelings of their parents regarding their musical activities:

Ellos estan contentos, les gusta que esté haciendo algo bueno con mi tiempo [They [my parents] are happy; they like that I am doing something productive with my time] (Student Survey). 
Tratan de ir a todos los conciertos, toda mi familia me dice "que bueno lo que estoy haciendo" [They try to go to every concert. All my family tells me that I am doing something well]. (Student survey)

Mi familia me conoce como la música de la familia, les gusta que toque el violín. Aunque nos cuesta venir a los ensayos, clases y conciertos, ellos siempre nos apoyan, especialmente mi mama [My family knows me as the musician of the family, they like that I play violin. Although we have transportation problems when attending rehearsals, lessons and concerts, my parents always support me, specially my Mom] (Student survey)

Mi familia dice que no importa que es lo que yo quiera hacer, siempre y cuando lo haga bien [My family says to me that it doesn't matter what I want to do, as long as I do it right]. (Student interview)

Most parents expressed support for their children's participation in the GMO.

Their perception that participation is something beneficial and perhaps integral to the development of their children is seen in the following statements:

Yo me siento felíz y aliviada de saber que mi hijo esta haciendo algo que valga la pena [I am happy and relieved knowing that my son is doing something worthy] (Parent interview).

Aunque a veces es muy difícil traerlo a las clases casi todos los días, nosotros siempre lo apoyamos porque a él le gusta mucho y es felíz [Even it is difficult to come almost every day, we - both parents - always support him because he likes to be here a lot, and he is happy]. (Parent survey)

Que él esté aquí me parece excelente porque a el le encanta, es económico y seguro. Además esta haciendo algo productivo [The fact that he is a part of the GMO is wonderful for me because he loves it and it is economical and safe. Also, he is doing something productive] (Parent survey]

Two students reported that their parents were not completely satisfied with their involvement in the GMO. Marcos (all names are pseudonyms) explains that his parents think that music should not be his first priority: "Ellos me dicen que esta bueno que toque, pero que el colegio es primero" [My parents tell me that it is good I am playing music, but the school — regular school— comes first] (Student interview). Likewise, Elena explains that her parents are happy with her participation at the GMO, but they are concerned about her future, stating: "Mis papas me dicen: "que 
bueno que me guste la música, pero que de músico en Guatemala me voy a morir de hambre” [My parents say that it is good thing that I like music, but that as a musician in Guatemala, I will die of hunger] (Student interview). Noteworthy here is the fact that during my last visit to the orchestra, I noticed Elena's absence in rehearsals (Field Notes). I asked her friends what happened and one of them said: "Ella ya no esta tocando, los papas la sacaron porque tiene que estar mas enfocada en el colegio" [She is not playing anymore, her parents told her that she needs to focus more on school regular school] (Student interview).

Elena's case is an example of what Hallam (2011) affirms about the lack of parental support: "where parents are indifferent or less involved, children are likely to give up playing” (p. 270). While it is impossible to predict if GMO members will abandon music in the future, this study shows participants who, regardless of parental support, have been engaged with their musical development for more than three years. Rony, a 21-year-old upright bass player, explains that his parents do not agree with his music career, and although he respects their opinion, he wants to be a professional musician (Student interview). The same is true of Estuardo who says:

Mis papas no me apoyan porque dicen que no puedo ganar dinero con la música, pero no les hago caso porque esto es lo que me gusta, lo que me apasiona.... así que voy a seguir mi sueño de ser músico [My parents do not support my decision because they say I cannot make money with music, but I do not agree. Music is what I am passionate about, so I will follow my dream of being a musician] (Student interview)

Regarding the lack of parental support, Hewitt and Allan (2013) explain that while parental support towards music making is crucial in the first stages of childhood, during adolescence youth do not need a "parental interest or influence to develop an interest in music if the activity itself is sufficiently attractive and impactful” (p. 258). The cases of Rony and Estuardo demonstrate the existence of a 
different kind of motivation, something intrinsic, as well as the contributing impact that the GMO environment might play in supporting said intrinsic motivation or in generating other extrinsic factors, that counter-balance parental disapproval or positively reinforce parental support. Beside parental support, there are other possible external motivators, such as teachers and peer support.

Teacher as role model. Hallam (2011) states that "the relationship between pupil and teacher, the sensitivity of the communication between them and the extent to which the student has a sense of autonomy all have an impact on learners' liking for music” (p. 270). In the GMO environment, teachers are in charge of the selection and of organizing the content, and also conduct the tutoring and evaluation of students' instrumental technique and repertoire performance. According to the academic director, although not all teachers at the GMO have a degree in music education, the GMO faculty is representative of the best options available in Guatemala; teachers are perceived as excellent musicians who can inspire students (Academic director interview, paraphrase). Moore, Burland and Davison (2003) state that, “an inspiring teacher may be essential to engage a child with a new domain” (p. 530). This sense of admiration from students was clearly noted throughout the data collection. Two clarinet players, exemplified this by saying:

Yo quiero ser como el profe porque toca super bien y es rebuena onda [I want to be like my clarinet teacher because he is a really good musician and also a really good friend] (Student interview).

Cuando lo veo tocar me inspiro y me dan ganas de estudiar más, lo bueno es que el comparte con todos lo que sabe [He inspired me to study more; A good thing is that he shares his knowledge with anyone] (Student interview).

Silvia, the mother of one of these children also affirms:

Siempre estan practicando la lección que él les deja. Ellos lo ven como un ejemplo a seguir [They are always practicing the music material that he assigns them. They look at him as a role mode] (Parent interview). 
Although it is not stated as a specific methodology for promoting students'

motivation on the GMO curriculum, the teachers use praising and giving honest feedback as ways of nurturing students' motivation. One of these teachers who is a well-known musician in Guatemala and who has studied abroad in highly regarded music schools explains:

Yo trato de animarlos y motivarlos diciendoles lo que hacen bien pero también que es lo que tienen que mejorar. Casi siempre ellos tratan de mejorar en cada lección. Hay algunos que les cuesta menos, pero al final la idea es que todos siguan mejorando y no dejen el instrumento ya que muchos alumnos pasan muchas penas para venir, no todos tiene las mismas condiciones económicas [I try to motivate my students telling them what they are doing well but also what they need to improve. Almost everyone tries to improve in each lesson. There are some students who struggle less with the lesson, but the idea is that all of them continually improve and do not give up because there are many students that have many troubles to come. Not everyone has the same economic possibilities]. (Teacher interview)

The data indicate the important role of teacher's feedback on the student's musical motivation regarding individual characteristics. Sichivitsa (2007) explains that students are more motivated when they "perceive their teacher to be supportive and cooperative”...”and able to give immediate constructive feedback in a positive manner” (p. 56). At the GMO, this feedback is given from teachers in two different situations: in individual lessons by instrumental teachers and by the conductor during the orchestra rehearsals. The academic director explained, that despite the GMO not having a specific guide for giving students feedback, faculty tries to praise what students are doing well while giving suggestions on how to improve weak areas. He adds that teachers generally consider the students' background in their feedback.

One teacher said that sometimes he accepts nonattendance when children do not have transportation to arrive to school or to return to their houses. He adds:

En estos casos trato de dejarles material para que ellos estudien en sus casas y les digo que me pueden llamar por telefono si necesitan algo. [In these cases, I 
assign them special homework. Further, I tell them they can call me if they need something].

These curricular adaptations made by teachers according to the students' needs may be connected with a participative approach of musical literacy in the GMO.

According to Shor (1999), the essence of participatory literacy is "allowing the issues and concerns that preoccupy students to become the motor force of instruction, the starting point for curriculum development has to be an understanding of student's lives, their backgrounds, personal histories, strengths, and current situations” (p. 32). The understanding of individual backgrounds allows teachers to give specific feedback to every student thus facilitating motivation, which is also sought from peers.

Peer support. This is another clear source of motivation for the GMO members as part of its implicit curriculum. The literature shows that the influence of peers is vital in the decision for children and youth to continue their musical development or enrollment in a musical ensemble (Allen, 1981; Burland and Davidson, 2004; Hallam, 2011) and the experiences at GMP corroborate these findings.

It is important to know that peer-support has a level of structural support. The academic director expressed that peer support could be observed in many situations at GMO, whether in terms of learning, logistical elements such as transportation, and/or socio-emotional problems (Director interview). Sichivitsa (2007) states “peer support and peer tutoring may help students feel more comfortable in a classroom, and thus motivate them to actively engage in music making and performance” (p. 56). A mother of one child expressed:

A veces los amigos de mi hijo no tiene como irse de regreso a su casa entonces el me pide que los lleve, de lo contrario ellos ya no vendrian a los ensayos o a los conciertos [Sometimes my son's friends do not have a way to come back to 
their houses, so I give them a ride. Otherwise, they cannot attend concerts and rehearsals]. (Mother interview)

Moreover, four students exemplify how peer support may be helping their experiences at the GMO:

Aquí nos conocemos y nos contamos todo.... las tristezas y las alegrías [Here, we know everything about each other, the sorrows and joys] (Student survey)

A veces mis amigos me prestan dinero para comer o para tomar la camioneta. Así, yo puedo venir a los ensayos [Sometimes my friends lend me money for food or transportation, and thus I can attend rehearsals] (Student interview)

Cuando no teníamos maestro, el principal de la sección nos enseñaba y después nosotros le enseñábamos a los otros [When we did not have a teacher, the sectional principal taught us and then we taught others] (Student Interview)

These statements show the different levels — socio-emotional, learning, and logistic — in which peers support each other and how it contributes to their attendance to the GMO's activities. Furthermore, it is noticed that this helping is extended to musical material in peer-learning relations.

Data reveal peer learning as a key factor in the development of motivation in the GMO environment. Boud, Cohen and Sampson (1999) define peer learning as "the use of teaching and learning strategies in which students learn with and from each other without the immediate intervention of teacher” (p. 413). Within the GMO environment, students constantly face different musical issues and challenges not addressed in their personal lessons, such as the reading and playability of difficult musical passages.

During one observation, I noticed with great interest how Luis, the leader of the violin section, was explaining to Carlos the correct rhythms in a violin partita:

No es difícil, pero tienes que practicarlo despacio de primero y luego un poco más rápido y más rápido hasta que lo tengas a la velocidad que es [It is not difficult, but first you need to practice it slow and then faster and faster until you can play it at normal speed] (Researcher observation). 
According to the trumpet teacher, since they often do not have time for correcting or helping students with these specific issues, students create situations where they teach each other without any instructions from adult figures. In these situations, Green (2008) identifies a "peer-directed learning” that involves the conscious sharing of knowledge and skills” through demonstration and imitation (p.

7). For instance, three students said:

Yo aprendo mucho de mis amigos de sección, si hay algo en las partituras que es muy difícil les pido ayuda.... Entonces ellos lo tocan primero despacio para que yo mire como se hace [I learn a lot from my section peer. If there is something difficult in my music, I ask them for help. Then, they play slowly in order for me to see and learn how to do it] (Student interview)

Muchas veces estudiamos cosas de la orquesta, pero muchas veces compartimos cosas de la trompeta, como tocar notas agudas, o pedazos de solos que nos gustan [Many times we study something related with what we are playing in orchestra, but also many times we share things about the trumpet, such as how to play high notes or trumpet solos we like].

Pues no tenemos horario para juntarnos, es cuando sea, a veces nos juntamos en los descansos de la orquesta, antes de los concierto [We do not have schedule to meet. It is whenever; sometimes we meet to talk or study during the orchestra's breaks or before concerts.

The above quotations suggest strong connections with the participatory literacy fundamentals that position the learner at the center of curricular development. Within the peer-learning experiences of the GMO, students have significant participation in content selection and the approach to teach it and to learn it; they are in control of what to study and how to study. Jurma (1987) explains that, for participatory literacy to happen it is necessary that learners "have greater degrees of control, responsibility, and reward” instead of just being “present (physically or on paper) in the program” (p. 16).

Regarding active participation, most of the GMO's members shared their experiences in both learning from others and teaching others, something that Boud et 
al. (1999) call “peer-reciprocal learning” in which "students within a given cohort act as both teachers and learners” (p. 414). The following testimonials exemplify teaching peer-reciprocal learning in the GMO context:

Me gusta ayudar enseñando lo que sé porque me hace refrescar lo aprendido, además yo he aprendido mucho de mis compañeros [I like to teach what I know because it makes me refresh what I have learned in the past. Furthermore, I have learned a lot from my peers, so it is my responsibility to teach others]. (Student survey)

Todos mis compañeros tienen un nivel bastante bueno y entre todos nos apoyamos para mejorar, si hay algo que no se le pregunto al otro. Y si el otro no sabe algo me pregunta a mi” [Everyone of my peers has a good level good musicians-, and everyone supports each other. If I do not know something, I ask one of my peers and if one of them doesn't know something, they ask me] (Student survey)

Hay unos que saben más de teoría y otros de técnica; Por lo tanto entre todos nos ayudamos eso si cuando podemos y sabemos del tema” [There are people who know more about music theory and others about technique; thus, we help each other, if we know the subject] (Student Survey).

The prior statements show how the GMO’s peer learning has implicitly

created a process of being aware about "what I do not know" and "how I can come to know it”. This may be connected with what Paulo Freire calls "unfinishedness”, that is the critical awareness of being uncompleted and in constant creation (Webb, 2010; Freire, 1998). This awareness in the GMO context may motivate members' curiosity to learn from more advanced peers, as they see them as individuals who have different abilities from which they can benefit and that interest them.

In the GMO, the faculty implies pedagogical considerations regarding peer learning and the sharing of knowledge. Most teachers think it is beneficial for students to teach each other because it reinforces what they learn during the lessons. For example:

Yo siempre les digo de que compartan con sus compañeros de sección lo que aprenden en la clase así como lo que aprenden en distintos conciertos y seminarios con otros profesores. [I always tell them to share with their section 
mates what they learn, not just in the classroom, but also in different experiences in concerts and seminars]”. (Teacher interview)

Based on data presented in this section, it is clear that peer support and peer learning, both embodied in the implicit curriculum of the GMO, play an important role in the motivation and musical development of the GMO's members. However, as significant for this study, is the existence of a participative literacy, where skills as well as social and emotive learning are being developed. It is also apparent that the GMO structure is a learning, organizational, and physical space that facilitates this process.

While data presented in this section indicate the important role of peer support on participant's motivation for attending the GMO, it also uncovers organizational and financial problems that the GMO community is currently facing, specially the low budget for hiring teachers and the improvement of activity logistics. Although these problems are not part of the current study, it is pertinent to indicate that these issues may affect the future of students' motivations to attend the GMO activities as well as their parental support.

Musical aspirations as motivator. As a sub-theme, intrinsic motivation emerged primarily from students' own considerations for attending the GMO and musings regarding how families and teachers perceive this participation. Not surprisingly, most students emphasized "music" as the key motivator for their participation in the GMO, which is corroborated by the following statements:

Yo toco y estudio porque me gusta, es algo que me nace del corazón [I play and study music because I like it. It is something that comes from my heart] (Student interview)

Mi vida es la música y eso es lo que quiero hacer siempre [My life is music and that is what I want to do always] (Student survey) 
Silvia, a parent of two musicians, explains that her children attend the GMO’s activities voluntarily; they enjoy playing at rehearsals and concerts, and they are not obligated by anyone to go. During the interview with the academic director, he constantly emphasized how musicians in the GMO display a marked sense of motivation, easily engaging with the orchestra's activities. He states:

Ellos asisten a la mayoría de los ensayos a pesar de que no les pagan, que muchos no tienen como irse a sus casas cuando es tarde y a veces los regañan por que no les da tiempo para hacer los deberes del colegio [They attend most of the rehearsals despite the fact that there are no costs and no one is getting paid, or regardless of the fact that they need to figure out how to get back home when it is late at night, and many times they have to deal with angry parents and teachers because they did not have time to finish school homework]. (Academic director interview)

Although the purpose of this study is not to determine if playing music is the most important motivator for their assistance to the orchestra, there is data portraying their aspirations for being professional musicians and its connection with the GMO environment. In this study, aspiration is a defining characteristic of someone who "is involved in various activities for both their inherent value and enjoyment and their connection to future goals” (Quaglia and Cobb, 127). The GMO’s members expressed these feelings on several occasions:

Estudio música porque amo la música y me veo en el futuro como músico profesional [I study music because I love music. In the future, I see myself as a professional musician] (Student interview)

Quiero ser violinista professional para tocar piezas de gran magnitud y poder tocar en una orquesta profesional [I want to be a professional violinist and play magnificent music in a professional orchestra] (Student Survey).

Quiero llegar a ser un chelista profesional, vivir de ello, ser concertista, ir a varios lugares del mundo, pero más que nada, ser artista [I want to be a professional cellist and travel around the world. I want to be an artist] (Student survey)

Yo quiero seguir estudiando música para tener mejores oportunidades en la vida, quiero ser profesional como los maestros que nos visitan y nos dan clases [I want to continue studying music because I want to have better opportunities 
in my life. I want to be professional like the professors we have had in different workshops as well as our teachers at GMO]. (Student Interview]

The motivational tension between continuing one's musical studies and the aspiration of becoming a professional musician is reinforced by the external motivators, principally parents, peers, and teachers. The motivators serve as "sources of reward,” providing feedback that may influence the students self-esteem and selfefficacy (Hallam, 2011, p. 270). We see the GMO then functioning as a repository and catalyst for these two kinds of motivation, and consequently playing a role in the literacy development of these students that deserves attention, the results of which I will discuss further in the conclusions.

Although data do not allow identifying the origins of these students' intrinsic motivations, it is noticed how this is something powerful for their ongoing musical development. As Hallam (2011) explains, for continuing to learn to play an instrument over a long period of time, as voluntary activity, the existence of an intrinsic motivation is paramount (p. 271).

Aspiration is a signal of intrinsic motivation that may be linked with the Critical Literacy concept of "read the world and the word", which is defined as a dialectical relationship of understanding our context and rewriting it (Freire and Macedo, 1987).

In the GMO context, music is the way by which the students are learning to read the world and writing it in a different way. Data show that even with difficulties — exemplified in economical issues such as transportation — they are pursuing their aspirations. Students may be reading their context (world) through the music (word) and in turn, they are rewriting their future contexts and aspirations. 


\section{CONCLUSIONS}

The Guatemala Municipal Orchestra (GMO) is a musical ensemble dedicated to work with youth and children in underserved areas of Guatemala City. Based on the Venezuelan music program known as El Sistema (Escuela Municipal de Música, 2013), the GMO functions according to many of the same underpinning philosophies as its predecessor in Venezuela, yet, has developed its own distinct traits based on the Guatemalan context. Press, government advocacy, and international institutions have boosted many positive effects for the members as a result of their participation. These effects are not strictly musical, but also socially significant, impacting their relationships inside and outside of the program. Conversely, their relationships outside the program influence relationships inside the realm of the orchestra. The present study sought to uncover the impact of the GMO's curriculum on its members, not only as perceived by the researcher but also by the young musicians within the organization.

Based on the conjecture that carefully constructed musical interactions can perhaps direct the process of socialization, careful qualitative analysis of the GMO's different elements brings one interpretation and an understanding of the complex social relationships formed within this musical context. Data was collected through triangulation, approaching the study from several different perspectives. These viewpoints were unveiled through interviews with the students, parents, teachers, and directors of the GMO, surveys with students and parents, and researcher observations during ensemble rehearsals. The intersection of these different perceptions helped establish validity in the study and created a complex arrangement of information for the researcher to interpret. 
Axial coding was used to sort the data into its two main themes. Once separated, underlying subthemes emerged and provided the framework for deeper interrogation. Through scrutiny of the data and interpretive analysis, the researcher was able to draw conclusions as to how the curriculum of the GMO has become such an integral part of members' lives. In any type of data analysis, there will always exist varied degrees of bias, since the researcher chooses which information to analyze. As is the case in any qualitative study, complete objectivity is impossible.

\section{Addressing Research Questions}

The following research questions framed this research study:

Research Question 1. What, if any, is the influence of the Guatemala Municipal Orchestra's music curriculum upon the social interactions of its members?

Data analysis shows how the GMO provides a learning and communal environment where youth develop musical and social skills through interactions among teachers and students during rehearsals, concerts, individual lessons, and peer learning situations. These social skills are evident in the development of soft skills such as discipline, responsibility, and self-control. These skills are being applied in different contexts inside and outside of the GMO environment.

Students are well aware of their active participation in the structure of the GMO community, since they are playing different roles as teachers, students, and artists, all demanding interaction with adults and peers. This structure, in turn, seems to be porous enough that it provides students with the opportunity to understand and recognize the labor of the conductor, instrumental teachers, and others, facilitating further awareness of the complex but delicate relationship that is in place; this contributes to both a sense of community and a higher 'buy-in' into the program. 
The youth in the GMO expressed a sense of community that implies an awareness of belonging and a bidirectional influence from and to the orchestra. Students expressed and demonstrated responsibility for attending GMO activities, since they feel a part of it; the success of the orchestra is their own success. This dynamic reinforces their sense of belonging and the bidirectional influence acting as a virtuous cycle.

Students perceive the GMO as a physical and emotional space for learning and sharing, where peer learning is the key element. It allows the students to develop social skills because of the constant interaction with peers. Within this context, the students have the experience of teaching and to be taught, a situation that Freire (1990) explains as “teacher-student and student-teacher” relations and notes as essential in learning (p. 67). This continuum fits with the tenets of participatory literacy, since the students have an active participation in the curricular design when selecting and discriminating content.

Another characteristic present in participatory literacy is the critical awareness of the students as unfinished human beings. This critical awareness is mirrored with the presence of students’ aspirations for professional musical development. Students perceive the role of teachers and musician guests as external motivators, not only as sources of reward, but also as role models that help visualize what means to be professional.

Research Question 2. How do teachers, participating in the GMO, perceive the curricular structure and how it facilitates social interactions?

Since the GMO does not have an explicit curriculum defining teachers’ responsibilities toward content and instruction, teachers have designed and 
implemented their own curriculum, which is applied toward individual lessons according to their own criteria and judgment.

Curricular content is developed according to teachers' previous music experiences as musicians and as teachers. Attending to the repertoire demanded by the orchestra is the main factors in the selection of the content taught during the lessons. Nonetheless, teachers perceive the curriculum as flexible, particularly when they need to do modifications according to the students' necessities and abilities. Teachers are often flexible, giving students feedback that takes in consideration their backgrounds and limitations, while seeking a positive reinforcement grounded in students’ capabilities and their needs. This is connected with the tenets of Participatory Literacy, where the students’ background and context are central for the curriculum development.

While teachers perceive curriculum as flexible in some aspects, they notice that the amount of students they need to attend to limits the time that they can dedicate to every student. They perceive that their inability to reach all students oneon-one, generates planned peer learning meetings among more advanced students and students in lower levels. Likewise, the lack of teacher to student interaction at times might be contributing to spontaneous peer learning meetings where the students are responsible for the content selection according to their interest. Teachers perceive peer-learning situations as beneficial for students engaged in these encounters, since they represent opportunities to reinforce previous learning and to share knowledge.

Teachers perceive the GMO environment as a learning space where they attempt to optimize role models that motivate students' aspirations to continue musical studies in the GMO and perhaps beyond. Finally, teachers' reflections expose the GMO environment as a space where different situations, planned and 
spontaneous, can be found that are fostering and provoking social interactions for the students.

Research Question 3. How does the leadership of the GMO perceive the curricular structure and how it facilitates social relationships?

Although from its beginning the GMO has been working under the premises established by El Sistema in Venezuela, the leadership is currently implementing a new process of curricular development based on the lessons learned during the last seven years of experiences with the Guatemalan context. Even though there is not an official curriculum for the Guatemala Municipal Orchestra (GMO), the implicit and de facto curricula are implemented, allowing different situations that involve social interactions among the GMO community. Since leaders in the GMO are interested in developing a new curricular proposal, their awareness of the need for philosophical and technical guidelines, that would frame the development of future GMO activities, is evident.

The GMO structure facilitates a sense of community where bidirectional influence between students and the GMO as an institution is present. The influence of students on the GMO is evidenced in how leadership in the GMO attends to the students' request for an official degree, certifying their musical studies. For example, currently leadership is working toward such an official degree, authorized by the Ministry of Education of Guatemala. This fact fits within a significant element of participatory literacy that focuses on "the issues and concerns that preoccupy students" and how they can "become the motor force of instruction” (Shor, 1999, p. $32)$.

On the other hand, the GMO influences students by creating the emotional, learning, and physical space for developing a sense of community where different 
social interactions situations occur, the most prominent being peer-learning. The GMO leadership is conscious of both the benefits and the economical difficulties behind the planned peer learning encounters. On the one hand, the GMO administration recognizes the social values that peer learning provides, since students develop soft skills through their roles as “student-teacher and teacher-student”. On the other hand, due to financial issues that the GMO is facing, peer learning emerges as an alternative strategy for teaching that can also be understood to be quite problematic, as youth can often be unprepared to address learning issues that are complex and require keen pedagogical understanding.

The GMO leadership recognizes the importance of the teacher role model in the students' aspirations to continue musical studies, at the institution and beyond, and become professional musicians. This is mirroring the leadership's main reason to hire teachers that they consider excellent musicians, regardless of not having a music education degree. These individuals represent the physical image of a professional musician because of their musical experience and reputation.

Finally, even if the new curricular proposal is not yet fully implemented, the current structure for the GMO serves as a space for the students' social and musical development. The sense of community peer learning and the students' aspirations to be professional musicians are the aftermath of an implicit or hidden curriculum that is unintended and in many cases spontaneous. There is evidence, however, that said implicit curriculum is becoming a de facto curriculum enacted by all the members of the GMO community. This curriculum is an element that requires greater attention from the administration and more careful guidance in the future. 


\section{Unexpected and Emerging Themes}

During coding and analyzing data, different themes emerged that were not addressed in this study since they are not relevant for answering the research questions.

Finantials Issues at the GMO. During several interviews, students and parents expressed their concerns about appropriate logistics when concerts and rehearsals finished late. There are testimonials about how youth need to walk in the night to return to their houses, a situation that is aggravated by the high index of violence in Guatemala. When I asked the administrative director, she informed me that the municipality provides transportation from the GMO headquarters to the concert location and back, but once in the school, every member needs to figure out how to return to their homes [Administrative director interview].

While this study showed how the GMO leadership is considering the students' opinions and needs for the curricular development, data unveiled that students' context are not taken into account for the logistics of the GMO concerts. The majority of the GMO’s performances are the Conciertos de Barrio organized by The Municipality of Guatemala City that is the principal funder of the GMO. The academic director explained that the GMO performs in these concerts as part of the responsibilities and obligations that this orchestra has with the funder. Logistical problems such as transportation, distance (walking long distances) and time (late night walks), often inconvenience students that must attend these concerts and pose a threat to their safety.

Sustainability of the GMO. Leadership and faculty expressed their concern about the sustainability of the GMO, since it depends directly on the mayor's office of the Municipality of Guatemala City. It is important that the current mayor has been 
running the Municipality since 2004 and funding the GMO since 2007. The issue is what level of priority the GMO would have if someone else runs the municipality. These conditions keep the GMO sustainability susceptible to the Guatemalan political context.

\section{Implications for Future Research}

The significance in this study lies not only in addressing the research questions established a priori, but also in exploring and uncovering future investigative topics. Through the findings of this study, I see numerous opportunities for potential studies.

First, this case study revealed the sense of community in the GMO environment. Insofar as GMO has been working since 2006, future research may uncover what has been the impact of this orchestra on the different social communities linked with GMO, such as students' families, schools, churches, and neighborhoods.

Second, new investigations may explore other outcomes related with youth participation in the GMO community that were not addressed in this study. Since Guatemala is a country with high levels of social injustice (World Bank, 2014, Guatemala, para. 6), it could be meaningful to analyze if initiatives, such as the GMO, may influence in fostering social justice.

Finally, further research on the present study can be conducted to discover if the GMO curricular structure creates spaces for the development of creativity among students. 


\section{REFERENCES}

Abrahms, F. (2005). The application of critical Pedagogy to Music Teaching and Learning: A literature Review. Applications of Research in Music Education, 23, 1222. Retrieved from http://upd.sagepub.com.ezproxy.fiu.edu/content/23/2/12.full.pdf+html

Ackerman, P. L. (1996). A theory of adult intellectual development: Process, personality, interests, and knowledge. Intelligence, 22(2), 227-257.

Altenmüller, E., Demorest, S.M., Fujioka, T., Halpern, A.R., Hannon, E.E., Loui, P., Majno, M., Oechslin, M.S., Osborne, N., Overy, K., Palmer, C., Peretz, I., Pfordresher, P.Q., Särkämö, T., Wan, C.Y. and Zatorre, R.J. (2012), Introduction to The Neurosciences and Music IV: Learning and Memory. Annals of the New York Academy of Sciences, 1252(1), 1-16.

Anderson, J. C., Funk, J. B., Elliott, R., and Smith, P. H. (2003). Parental support and pressure and children's extracurricular activities: Relationships with amount of involvement and affective experience of participation. Journal of Applied Developmental Psychology, 24(2), 241-257.

Apel, W. (1969). Harvard dictionary of music. Cambridge, MA: Belknap Press of Harvard University Press.

Arts Education Partnership. (2012). Music Matters: how music education helps students learn, achieve, and succeed. Retrieved from http://www.aep-arts.org/wpcontent/uploads/2012/08/Music-Matters-Final.pdf

Baker, G. (2013). Scam, Voodoo, or The Future of Music? The El Sistema Debate. Retrieved from http://geoffbakermusic.wordpress.com/el-sistema-the-system/elsistema-blog/scam-voodoo-or-the-future-of-music-the-el-sistema-debate/

Beck, M. S., Bryman, A., and Liao, T. F. (2004). The Sage encyclopedia of social science research methods. Thousand Oaks, CA: Sage.

Blake, N. (2003). The Blackwell guide to the philosophy of education. Oxford, UK: Blackwell Pub.

Bogdan, R., and Biklen, S. K. (1992). Qualitative research for education: an introduction to theory and methods. Boston, MA: Allyn and Bacon.

Bong, M., and Skaalvik, E. M. (2003). Academic self-concept and self-efficacy: How different are they really?. Educational psychology review, 15(1), 1-40.

Booth, E. (2010). El Sistemas’s Open Secrets. Retrieved from http://apo.co.nz/wpcontent/uploads/el_sistema_booth.2.pdf

Booth, E. (2012). The fundamentals of El Sistema. Retrieved from http://ericbooth.net/the-fundamentals-of-el-Sistema/ 
Borg, W. R., and Gall, J. P. (1992). Applying educational research: a practical guide for teachers. White Plains, NY: Longman Pub. Group.

Broh, B.A. (2002) Linking extracurricular programming to academic achievement: who benefits and why?. Sociology of Education, 75, 69-95.

Brown, J.D. (1980) Identifying problems facing the school band movement. Elkhart, IN: Gemeinhardt Co. Ltd

Campbell, P., and Burnaby, B. (Eds.). (2001). Participatory practices in adult education. Mahwah, NY: Lawrence Erlbaum Associates, Inc.

Canestrari, A. S., and Marlowe, B. A. (2004). Educational foundations: an anthology of critical readings. Thousand Oaks, CA: Sage Publications.

Cary, R. (1998). Critical art pedagogy: foundations for postmodern art education. New York, NY: Garland Pub.

Cassell, C., and Symon, G. (2004). Essential guide to qualitative methods in organizational research. London, England: Sage Publications.

Caznok, Y. (2013). La Educacion musical como profilaxis social. Retrieved from http://www.latinoamerica-musica.net/ensenanza/yara/sitio-Yara-esp.pdf

Charles, C. M. (1988). Introduction to educational research. New York: Longman.

Chavis, D. M., Hogge, J. H., McMillan, D. W., and Wandersman, A. (1986). Sense of community through Brunswik's lens: A first look. Journal of community psychology, 14(1), 24-40.

Clark, J. C. (2013). A qualitative exploration of higher self-efficacy string students preparing for a competition. International Journal of Music Education, 31(1), 4-14.

Cope, M. (2005). Coding qualitative data. Qualitative research methods in human geography, 2, 223-233.

Corbin, J. M., and Strauss, A. (1990). Grounded theory research: Procedures, canons, and evaluative criteria. Qualitative sociology, 13(1), 3-21.

Day, E. (2008). Why are our orchestras so white?. The Guardian. Retrieved from http://www.theguardian.com/culture/2008/sep/14/music.classicalmusicandopera

DeMarrais, K. B., and Lapan, S. D. (2004). Foundations for research methods of inquiry in education and the social sciences. Mahwah, N.J.: L. Erlbaum Associates.

Denis, G. and Jouvelot, P. (2005). Motivation-driven educational game design: applying best practices to music education. In N. Lee (ed.), Advances in Computer 
Entertainment Technology (pp. 462-465). Retrieved from http://www.cri.ensmp.fr/classement/doc/A-365.pdf

Desforges, C., and Abouchaar, A. (2003). The impact of parental involvement, parental support and family education on pupil achievement and adjustment: A review of literature. London, England: DfES Publications.

Devroop, K. (2012). The Occupational Aspirations and Expectations of College Students Majoring in Jazz Studies. Journal of Research in Music Education, 59, 393405.

Dorantes, D. (2014). La Pianista Venezolana Gabriela Montero critica a Gustavo Dudamel. La Voz de Houston. Retrieved from http://lavoztx.com/news/2014/feb/13/la-pianista-venezolana-gabriela-montero-criticagu/\#sthash.FoRadhAp.5Dhd40sZ.dpbs

Eatock, C. (2014). From Venezuela to the World: Exporting El Sistema. Retrieved from http://www.colineatock.com/el-sistema.html

El Sistema USA. (2013). El Sistema Inspired Programs 2013-2013 Census Report Summary. Retrieved From http://elsistemausa.org/downloads/NAESIPCensusReportSummary2012-2013.pdf

El Sistema USA. (2013). El Sistema USA Retrieved from http://elsistemausa.org Ellis, M., Kisling, E., and Hackworth, R. G. (2014). Teaching soft skills employers' need. Community College Journal of Research and Practice, 38(5), 433-453.

Freire Institute. (2014). Concepts used by Paulo Freire. Retrieved from http://www.freire.org/component/easytagcloud/\%20conscientization

Freire, P. (1998). Pedagogy of freedom: ethics, democracy, and civic courage. Lanham, MD: Rowman and Littlefield Publishers.

Freire, P. (2000). Pedagogy of the oppressed. New York: Continuum.

Freire, P., and Macedo, D. P. (1987). Literacy: reading the word and the world. South Hadley, MA.: Bergin and Garvey Publishers.

Fundación Musical Simón Bolívar. (2014). Sistema Nacional de Orquestas y Coros Juveniles e Infantiles de Venezuela. Retrieved from http://fundamusical.org.ve

Gaztambide-Fernandez, R. (2008). The Artist in society: Understandings, Expectations, and Curriculum Implications. Curriculum inquiry, 38(3), 233-265.. Retrieved from http://smjegupr.net/wp-content/uploads/2013/02/Gaztambide-TheArtist-in-Society.pdf

Giroux, H. A. (2011). On critical pedagogy. New York, NY: Continuum International Publishing Group. 
Gorlewski, J. A. (2011). Power, resistance, and literacy writing for social justice. Charlotte, NC: Information Age Pub.

Govias, A. (2011). The five fundamentals of El Sistema. Retrieved from http://jonathangovias.com/2011/09/09/five-fundamentals-of-el-sistema-nowavailable-online-and-in-print/

Grbich, C. (2012). Qualitative data analysis: An introduction. Sage.

Gresham, F. M. (1986). Conceptual and Definitional issues in the Assessment of Children's Social Skills: Implications for Classifications and Training. Journal of Clinical Child Psychology, 15(1), 3-15.

Griffee, Dale. (2005). Research Tips: interview data collection. Journal of Research of Developmental Education. (28)3, 36-37. Retrieved from http://files.eric.ed.gov/fulltext/EJ718580.pdf

Gruenewald, D. (2003). The best of Both Worlds: A critical pedagogy of place. Educational Researcher, 32(3),1-12. Retrieved from http://edr.sagepub.com/content/32/4/3.full.pdf+html

Held, D. (1980). Introduction to critical theory: Horkheimer to Habermas. Berkeley, CA: University of California Press.

Hewitt, A., and Allan, A. (2013). Advanced youth music ensembles: Experiences of, and reasons for, participation. International Journal of Music Education, 31(3), 257275.

Hollinger. D. (2007). To play and to Fight: The Venezuelan system that Produced LA's Next Great Conductor.. Retrieved from http://www.sjsu.edu/faculty/diana.hollinger/research.html

Jurmo, P. (1989). The case for participatory literacy education. New Directions for Adult and Continuing Education, 1989(42), 17-28.

Kanpol, B. (1999). Critical pedagogy: An introduction. Greenwood Publishing Group.

Kentli, F. (2009). Comparison of Hidden Curriculum Theories. European Journal of Educational Studies, 1(2), 83-88. Retrieved from http://www.ozelacademy.com/EJES_v1n2_Kentli.pdf

Kvale, S., and Brinkmann, S. (2009). Interviews: learning the craft of qualitative research interviewing. Los Angeles, CA: Sage Publications.

Lankshear, C. (1993). Critical literacy politics, praxis, and the postmodern. Albany, NY: State University of New York Press. 
Lewison, Seely and Van Sluys. (2002).Taking on Critical Literacy: The Journey of Newcomers and Novices. Language Arts, 79(5), 382-392. retrieved from http://www.jstor.org/stable/41483258

Mackey, A. and Gass. S (2012). In Research methods in second language acquisition: A practical guide. Chichester, England: Blackwell Publishing Ltd.

Majno, M. (2012). From the model of El Sistema in Venezuela to current applications: learning and integration through collective music education. Annals of the New York Academy of Sciences, 1252(1), 56-64.

Manning, M. A. (2007). Self-concept and self-esteem in adolescents. Principal Leadership (Middle School Ed.), 7(6), 11-15.

Marshall, C., and Rossman, G. B. (1989). Designing qualitative research. Newbury Park, CA: Sage Publications.

Marshall, M. (2013). Criticizing El Sistema. Retrieved from http://marshallmarcus.wordpress.com/2012/07/18/a-dragonfly-in-rose-tinted-glasses/

Matson, J. (2009). Social Behavior and Skills in Children. Los Angeles, CA: Springer.

McLaren, P., and Kincheloe, J. L. (2007). Critical pedagogy: where are we now?. New York, NY: Peter Lang.

McMillan, D. W., \& Chavis, D. M. (1986). Sense of community: A definition and theory. Journal of community psychology, 14(1), 6-23.

McNeil, J. (1996). Curriculum: a comprehensive introduction. New York, NY: Harper Collins College Publishers.

McNeil, J. (2006). Contemporary curriculum in thought and action. Hoboken, NJ: J. Wiley and Sons.

Merriam, S. (1988). Case study research in education: a qualitative approach. San Francisco, CA: Jossey-Bass.

Merriam, S. (1998). Qualitative research and case study applications in education. San Francisco, CA: Jossey-Bass Publishers.

Merriam, S. (2002). Introduction to qualitative research. San Francisco, CA: JosseyBass Publishers.

Michelson, L. (1983). Social skills assessment and training with children: an empirically based handbook. New York, NY: Plenum Press.

Midgette, A. (2012 March 2). I dare you not to cry: on classical music and critical thinking. Washington Post. Retrieved from 
http://www.washingtonpost.com/blogs/classical-beat/post/i-dare-you-not-to-cry-onclassical-music-and-critical-thinking/2012/03/02/gIQAcYVwmR_blog.html

Moore, D. G., Burland, K., and Davidson, J. W. (2003). The social context of musical success: A developmental account. British Journal of Psychology, 94(4), 529-549.

Morrel, E. (2002). Toward a critical pedagogy of popular culture: Literacy development among urban youth. Journal of Adolescent and Adult Literacy. 46(1), 72-77

Morris, P., and Adamson, B. (2010). Curriculum, schooling, and society in Hong Kong. Hong Kong, China: Hong Kong University Press.

Morrow, R., and Torres, C. (2002). Reading Freire and Habermas: Critical Pedagogy and Transformative Social Change. New York, NY: Teachers College Press.

Morrow, V. (1994). Responsible children? Aspects of children's work and employment outside school in contemporary UK. In Mayall, B (Eds.), Children's childhoods: observed and experienced (pp. 128-143). London, England: Falmer

Municipalidad de Guatemala. (2013). Escuela Municipal de Música. Retrieved from http://cultura.muniguate.com/index.php/component/content/article/82-emm/514orquestajuvenil

National Assembly of State Arts Agencies. (2006). Critical Evidence: how the ARTS benefit student achievement. Retrieved from http://www.nasaa-arts.org/Research/KeyTopics/Arts-Education/critical-evidence.pdf

New England Conservatory. (2014). Sistema Fellows Program. Retrieved from http://necmusic.edu/sistema-fellowship

Packer, M. J. (2011). The science of qualitative research. New York, NY : Cambridge University Press.

Patten, M. L. (2001). Questionnaire research: a practical guide. Los Angeles, CA: Pyrczak Pub.

Pitts, S,E. (2007) Anything goes: A case study of extra-curricular musical participation in an English secondary school. Music Education Research, 9(1), 145165.

Popkewitz, T. S., and Fendler, L. (1999). Critical theories in education: changing terrains of knowledge and politics. New York, NY: Routledge.

Rao, M. S. (2012). Myths and Truths About Soft Skills. T+D, 66(5), 48-51.

Rauscher, F. (2009) The impact of music instruction on other skills. In Hallam, S., Cross, I and Thaut, M. (eds) The Oxford Handbook of Psychology of Music, pp 244252. Oxford: Oxford University Press. 
Rausher, F. (2003). Can Music Instruction Affect Children's Conitive Development?. Retrieved from http://files.eric.ed.gov/fulltext/ED480540.pdf

Roberts, P. (2000). Education, literacy, and humanization: Exploring the work of Paulo Freire. Westport, CT: Bergin and Garvey.

Rubin, K, Bukowski, M, and Parker, J. (2007). Peers, interactions, and Relationships. In Damon, W. and Lerner R (Eds.). Handbook of Child Psychology. (pp. 573-631). Hoboken, NJ: John Wiley and Sons.

Ryan, R. M., and Deci, E. L. (2000). Intrinsic and extrinsic motivations: Classic definitions and new directions. Contemporary educational psychology, 25(1), 54-67.

Ryan, R. M., and Deci, E. L. (2000). Self-determination theory and the facilitation of intrinsic motivation, social development, and well-being. American psychologist, 55(1), 68-78.

Saldaña, J. (2011). Fundamentals of qualitative research. New York, NY: Oxford University Press.

Sandow, G. (2010). El Sistema-troubling. Retrieved from http://www.artsjournal.com/sandow/2010/03/el_sistema_-_troubling.html

Schellenberg, E. G. (2005). Music and cognitive abilities. Current Directions in Psychological Science, 14(6), 317-320.

Schuler, H., Farr, J. L., and Smith, M. (1993). Personnel selection and assessment: Individual and organizational perspectives. Hillsdale, NY: Lawrence Eribaum Associates, Inc.

Schulz, B. (2008). The importance of soft skills: Education beyond academic knowledge. Nawa Journal of Language and Communication, 2(1), 146-154.

Segeplan. (2014). Indices de pobreza general y extrema. Gobierno de Guatemala. Retrieved from http://www.segeplan.gob.gt/downloads/IndicePobrezaGeneral_extremaXMunicipio.p df

Shakir, R. (2009). Soft skills at the Malaysian institutes of higher learning. Asia Pacific Education Review, 10(3), 309-315.

Shor, I. (1999). What is critical literacy?. Journal for Pedagogy, Pluralism and Practice 1(4). Retrieved from

http://newhavenleon.org/yahoo_site_admin/assets/docs/OutreachWhat_is_critical_lite racy_-_shor.13071914.pdf

Shor, I., and Pari, C. (1999). Critical literacy in action: writing words, changing worlds. Portsmouth, NH: Boynton/Cook Publishers. 
Sichivitsa, V. O. (2007). The influences of parents, teachers, peers and other factors on students' motivation in music. Research Studies in Music Education, 29(1), 55-68.

Sloboda, J. A. (1991). Musical expertise. In K. A. Ericsson and J. Smith (Eds.), Toward a general theory of expertise: prospects and limits (pp. 153-171).

Cambridge, UK: Cambridge University Press.

Smith, T. E., and Knapp, C. (2011). Sourcebook of experiential education: key thinkers and their contributions. New York, NY: Routledge.

Swanborn, P. (2010). Case Study research what, why and how?. London, England: Sage

TED. 2009. Jose Antonio Abreu: Let's bring music to kids worldwide [Video File]. Retrieved from http://www.youtube.com/watch?v=Uintr2QX-TU

The National Association for Music Education. (2012). The benefits of the study of Music: why we need music education in our schools. Retrieved from http://musiced.nafme.org/files/2012/04/benefits_of_music.pdf

The Scottish Government. (2011). Evaluation of Big Noise, Sistema Scotland. Edinburgh: Queens Printers of Scotland.

The University of Arizona (Producer). (2012, April 10). Critical Pedagogy: Learning from Freire's Pedagogy of the Oppressed [DVD]. A Forum on Ethich Studies, Academic Freedom, and the Value of Scholarship [Audio Podcast]. Available from http://gws.arizona.edu/http\%3A//gws.arizona.edu/EthnicStudies-April2012Event

Tunstall, T. (2012). Changing lives. New York: W.W. Norton and Company.

Unicef. (2014). Communication for Development. Retrieved from http://www.unicef.org/cbsc/index_42352.html

Vasil, M. (2013). Extrinsic Motivators Affecting Fourth-Grade Students' Interest and Enrollment in an Instrumental Music Program. Applications of Research in Music Education, 32(1), 74-82.

Wall, J., Covell, K., and MacIntyre, P. D. (1999). Implications of social supports for adolescents' education and career aspirations. Canadian Journal of Behavioral Science/Revue canadienne des sciences du comportement, 31(2), 63-71.

Wallowitz, L. (2008). Critical literacy as resistance: teaching for social justice across the secondary curriculum. New York, NY: Peter Lang.

Webb, D. (2010). Paulo Freire and 'the need for a kind of education in hope'. Cambridge journal of education, 40(4), 327-339.

Wold Bank. (2014). Guatemala Overview. Retrieved from http://www.worldbank.org/en/country/guatemala/overview 
Yin, R. K. (2003). Case study research: design and methods. Thousand Oaks, NY: Sage Publications.

Zou, Y., and Trueba, E. T. (2002). Ethnography and schools: qualitative approaches to the study of education. Lanham, MD.: Rowman and Littlefield Publishers. 
VIII. APPENDICES 


\section{FIU \\ UNIVERSIDAD INTERNACIONAL DE FLORIDA \\ CONSENTIMIENTO DEL MENOR}

La Influencia del Currículo de Estudios de la Orquesta Municipal de Guatemala en la Interacción Social de sus Miembros

¿POR QUÉ ESTÁS PARTICIPANDO EN ESTE ESTUDIO?

Nos gustaría que formaras parte de un estudio que estamos realizando. Un estudio de investigación es una manera de conocer información acerca de algún tema. Queremos conocer más acerca del ambiente de la Orquesta Municipal y así obtener un mejor entendimiento sobre cómo podría impactar el desarrollo musical y social de los jóvenes que participan en ella.

\section{¿CUÁNTAS PERSONAS MÁS HABRÁN EN ESTE ESTUDIO?}

Si te decides a participar en este estudio serás uno de 175 personas en el estudio de investigación.

\section{¿CUÁNTO VA A DURAR EL ESTUDIO?}

Tu participación requiere de tu asistencia a las actividades regulares de la orquesta durante los meses de septiembre a diciembre, 2013.

\section{¿QUÉ VA A SUCEDER EN EL ESTUDIO?}

Si accedes a ser parte del estudio se te solicitará que realices lo siguiente:

1. Participar en los ensayos normales

2. Ser observado durante las actividades del ensayo

3. Completar una encuesta

¿ME PUEDE SUCEDER ALGO MALO? No se conocen riesgos relacionados con tu participación en este estudio.

¿ME PUEDE SUCEDER ALGO BUENO? 
Los siguientes beneficios podrían estar relacionados con tu participación en este estudio:

Una mejor educación musical en tus escuelas

Una mejora en la forma en que opera la Orquesta Municipal de Guatemala

\section{EXISTEN OTRAS ALTERNATIVAS?}

No se conocen otras alternativas disponibles, únicamente la de no ser parte de este estudio.

¿HABRÁ ALGUIEN QUE SE ENTERE QUE SOY PARTE DE ESTE ESTUDIO? Los registros de este estudio se mantendrán privados y serán resguardados bajo la protección de la ley. En cualquier clase de que publiquemos no se incluirá ninguna información que pudiera identificarte. Los registros de la investigación se guardarán en forma segura y únicamente el equipo de la investigación tendrá acceso a los mismos.

\section{¿RECIBIRÉ ALGO A CAMBIO DE MI PARTICIPACIÓN?}

No recibirás ninguna compensación por tu participación. No serás responsable de ningún costo por participar en este estudio.

\section{¿QUÉ SUCEDE SI NO QUIERO PARTICIPAR?}

No tienes que formar parte de este estudio si no lo deseas y puedes retirarte del estudio en cualquier momento. Nadie se enojará si decides no participara

\section{¿CON QUIÉN PUEDO HABLAR EN RELACIÓN AL ESTUDIO?}

Si tienes cualquier pregunta acerca del estudio de investigación puedes comunicarte con Jacobo Nitsch Velásquez en Miami, al 415-656-5460, jnits001@fiu.edu.com o con el Dr. Patrick Schmidt a la dirección pschmi@fiu.edu. Si deseas hablar con alguien acerca de tus derechos como sujeto en este estudio de investigación puedes contactar a la Oficina de Integración de Investigaciones vía telefónica al 305-3482494 o al correo electrónico ori@fiu.edu. 


\section{CONSENTIMIENTO DEL PARTICIPANTE}

He recibido explicaciones sobre este estudio de investigación y estoy de acuerdo en participar en este estudio.

Firma del Menor que Participa

Fecha

Nombre del Menor que Participa

Firma de la Persona Receptora del Permiso

Fecha 


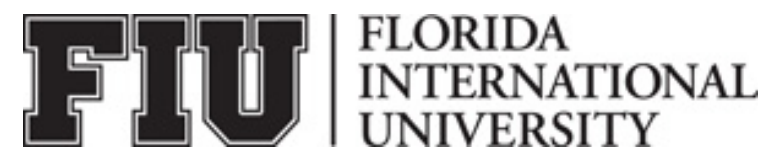

\section{UNIVERSIDAD INTERNACIONAL DE FLORIDA \\ CONSENTIMIENTO DE UN ADULTO PARA PARTICIPAR EN UN \\ ESTUDIO DE INVESTIGACIÓN}

\section{La Influencia del Currículo de Estudios de la Orquesta Municipal de Guatemala en la Interacción social de sus miembros}

\section{PROPÓSITO DEL ESTUDIO}

Se le solicita su participación en un estudio de investigación. El propósito de este estudio es investigar los posibles resultados sociales y educacionales en relación a su participación en la Orquesta Municipal de Guatemala. El objetivo es un mejor entendimiento sobre las formas en que se manifiestan estos resultados.

\section{NÚMERO DE PARTICIPANTES EN EL ESTUDIO}

Si se decide a participar en este estudio, usted sería uno de 175 personas en el estudio de investigación. Todos los participantes son miembros de la orquesta. DURACIÓN DEL ESTUDIO

Su participación requiere únicamente de la interacción normal con las actividades de la orquesta durante los meses de agosto y octubre.

\section{PROCEDIMIENTO}

Si accede a ser parte del estudio se le solicitará que realice lo siguiente:

1. Completar una encuesta

2. Participar en una entrevista semi-estructurada.

Esta entrevista será grabada en video y en audio.

\section{RIESGOS Y/O INCOMODIDADES -}

No se conoce riesgo o incomodidad asociada con este estudio.

\section{BENEFICIOS}


Potencialmente este estudio presentará la primera investigación profunda sobre el currículo de la $\mathrm{OMG}^{3}$ y su impacto en los niños y los jóvenes de Guatemala. Se podrían realizar cambios y probables mejoras al actual currículo de estudios derivados de la información obtenida. También es posible que surja la recomendación de nuevos centros de música o de centros reestructurados. Un mejor entendimiento sobre cómo perciben los jóvenes su experiencia en la OMG y el impacto que ésta podría tener en su crecimiento musical y social podría facilitar más adelante futuros cambios y mejoras al programa pedagógico y a la estructura.

\section{ALTERNATIVAS}

No se conocen otras alternativas disponibles, únicamente la de no ser parte de este estudio. Sin embargo, durante el curso de esta investigación se le informará de cualquier hallazgo significativo que pudiese ser relevante para su disposición de continuar su participación.

\section{CONFIDENCIALIDAD}

Los registros de este estudio se mantendrán privados y serán resguardados bajo la protección de la ley. En cualquier reporte que se publiquemos no se incluirá ninguna información que pudiese facilitar la identificación de un sujeto. Los registros de la investigación se guardarán en forma segura y únicamente el equipo de la investigación tendrá acceso a los mismos. Sin embargo, el registro de su información podría ser revisado con fines de auditoría, por agentes autorizados de la Universidad o por otros que estarán bajo las mismas regulaciones de privacidad.

\section{COMPENSACIÓN and COSTOS}

Usted no recibirá ninguna compensación por su participación. Usted no es responsable de ningún costo por participar en este estudio.

\section{DERECHO A DECLINAR O A RETIRARSE}

Su participación en este estudio es voluntaria. Tiene la libertad de participar en el estudio o de retirar su consentimiento en cualquier momento durante el estudio. Su retiro o falta de participación no afectará cualquier beneficio al que se tenga derecho. El investigador se reserva el derecho de retirar al participante sin su consentimiento cuando considere que es lo más conveniente.

\section{INFORMACIÓN DE CONTACTO DEL INVESTIGADOR}

\footnotetext{
${ }^{3}[\mathrm{NdT}]$ Orquesta Municipal de Guatemala
} 
Si tiene cualquier pregunta acerca del propósito, el procedimiento, o sobre cualquier otro tema en relación a este estudio de investigación puede comunicarse con Jacobo Nitsch Velásquez en Miami, al 415-656-5460, jnits001@fiu.edu.com o con el Dr. Patrick Schmidt a la dirección pschmi@fiu.edu.

\section{INFORMACIÓN DE CONTACTO DE LA JRI ${ }^{4}$}

Si desea hablar con alguien acerca de sus derechos como sujeto en este estudio de investigación o acerca de asuntos éticos de este estudio puede contactar a la Oficina de Integración de Investigaciones vía telefónica al 305-348-2494 o al correo electrónico ori@fiu.edu.

\section{CONSENTIMIENTO DEL PARTICIPANTE}

He leído la información en este formulario de participación y estoy de acuerdo en participar en este estudio. He tenido la oportunidad de hacer cualquier pregunta en relación a este estudio y he obtenido respuestas a mis preguntas. Entiendo que tengo el derecho a recibir una copia de este formulario después de que el mismo haya sido leído y firmado.

Firma del Participante

Fecha

Nombre impreso del Participante

Firma de la Persona Receptora

Fecha

\section{4 [NdT] Junta Revisora Institucional}




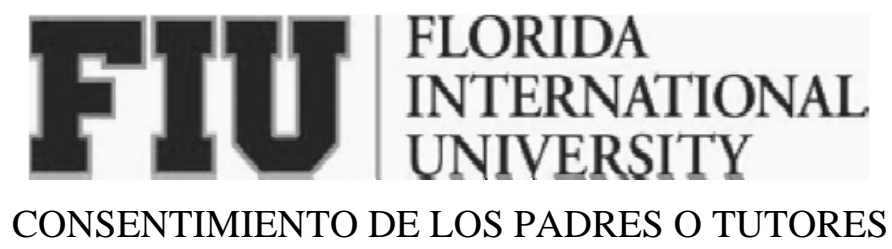

La Influencia del Currículo de Estudios de la Orquesta Municipal de Guatemala En la Interacción Social de sus Miembros

\section{PROPÓSITO DEL ESTUDIO}

Se le solicita la participación de su hijo/hija en un estudio de investigación. El propósito de este estudio es investigar los posibles resultados sociales y educacionales en relación a su participación en la Orquesta Municipal de Guatemala. El objetivo es un mejor entendimiento sobre las formas en que se manifiestan estos resultados.

\section{NÚMERO DE PARTICIPANTES EN EL ESTUDIO}

Si está de acuerdo en que su hijo/hija participe en este estudio, él/ella será una de las 175 personas en el estudio de investigación. Todos los participantes son miembros de la orquesta.

\section{DURACIÓN DEL ESTUDIO}

Su participación requiere únicamente de la interacción normal con las actividades de la orquesta durante los meses de agosto y octubre.

\section{PROCEDIMIENTO}

Si su hijo/hija participa en este estudio se le solicitará que realice lo siguiente:

1. Participar en los ensayos normales que serán grabados en video y en audio.

\section{Completar una encuesta}

\section{RIESGOS Y/O INCOMODIDADES}

No se conoce riesgo o incomodidad para su hijo/hija asociada con el desarrollo de este estudio más allá de los relacionados con su participación regular con la Orquesta Municipal de Guatemala.

BENEFICIOS Potencialmente este estudio presentará la primera investigación profunda sobre el currículo de la $\mathrm{OMG}^{5}$ y su impacto en los niños y los jóvenes de Guatemala. Se podrían realizar cambios y probables mejoras al actual currículo de estudios derivados de la información obtenida. También es posible que surja la recomendación de nuevos centros de música o de centros reestructurados. Un mejor

\footnotetext{
${ }^{5}[\mathrm{NdT}]$ Orquesta Municipal de Guatemala
} 
entendimiento sobre cómo perciben los jóvenes su experiencia en la OMG y el impacto que ésta podría tener en su crecimiento musical y social podría facilitar más adelante futuros cambios y mejoras al programa pedagógico y a la estructura.

\section{ALTERNATIVAS}

No se conocen otras alternativas disponibles para su hijo/hija, únicamente la de no ser parte de este estudio. Sin embargo, durante el curso de esta investigación se le informará de cualquier hallazgo significativo que pudiese ser relevante para la disposición del niño/niña de continuar su participación.

\section{CONFIDENCIALIDAD}

Los registros de este estudio se mantendrán privados y serán resguardados bajo la protección de la ley. En cualquier reporte que se publiquemos no se incluirá ninguna información que pudiese facilitar la identificación de un sujeto. Los registros de la investigación se guardarán en forma segura y únicamente el equipo de la investigación tendrá acceso a los mismos. Sin embargo, el registro de su información podría ser revisado con fines de auditoría, por agentes autorizados de la Universidad o por otros que estarán bajo las mismas regulaciones de privacidad.

\section{COMPENSACIÓN and COSTOS}

Su hijo/hija no recibirá ninguna compensación por su participación. Su hijo/hija no será responsable de ningún costo por participar en este estudio.

\section{DERECHO A DECLINAR O A RETIRARSE}

La participación de su hijo/hija en este estudio es voluntaria. Su hijo/hija tiene la libertad de participar en el estudio o de retirar su consentimiento en cualquier momento durante el estudio. Su retiro o falta de participación no afectará cualquier beneficio al que se tenga derecho. El investigador se reserva el derecho de retirar al niño/niña sin su consentimiento cuando considere que es lo más conveniente.

\section{INFORMACIÓN DE CONTACTO DEL INVESTIGADOR}

Si tiene cualquier pregunta acerca del propósito, el procedimiento, o sobre cualquier otro tema en relación a este estudio de investigación puede comunicarse con Jacobo Nitsch Velásquez en Miami, al 415-656-5460, jnits001@fiu.edu.com o con el Dr. Patrick Schmidt a la dirección pschmi@fiu.edu.

INFORMACIÓN DE CONTACTO DE LA JRI ${ }^{6}$

$\left.{ }^{6} 6 \mathrm{NdT}\right]$ Junta Revisora Institucional 
Si desea hablar con alguien acerca de los derechos de su hijo/hija derechos como sujeto en este estudio de investigación o acerca de asuntos éticos de este estudio puede contactar a la Oficina de Integración de Investigaciones vía telefónica al 305348-2494 o al correo electrónico ori@fiu.edu.

\section{CONSENTIMIENTO DEL PARTICIPANTE}

He leído la información en este formulario de participación y estoy de acuerdo en la participación de mi hijo/hija en este estudio. He tenido la oportunidad de hacer cualquier pregunta en relación a este estudio y he obtenido respuestas a mis preguntas. Entiendo que tengo el derecho a recibir una copia de este formulario después de que el mismo haya sido leído y firmado.

Firma del Padre/Madre/Guardián

Fecha

Nombre impreso del Padre/Madre/Guardián

Nombre impreso del menor Participante.

Firma de la Persona Receptora

Fecha 
Guatemala, July $25^{\text {th }} 2013$

To Whom it may concern,

This is to certify that I have reviewed and approved Jacobo Nitsch's proposal for the research study "The Influence Of The Guatemala Municipal Orchestra's Curriculum Upon The Social Interactions Of Its Members” at our Municipal School of Music. Thus, we agree to allow him to conduct research at this institution during September and October 2013. We understand all his research will be in compliance with our institution policies and procedures, the IRB, and all ethical considerations.

Sincerely,

\author{
Crista Foncea \\ Dirección de Educación y Cultura \\ Municipalidad de Guatemala \\ Director
}




\section{CUESTIONARIO PARA INTEGRANTES DE LA ORQUESTA MUNICIPAL DE GUATEMALA}

Nombre:

Edad:

Instrumento:

Sexo:

Instrucciones: Por favor, lee y contesta las siguientes

1. ¿Cuánto tiempo tienes de ser un miembro activo de la Orquesta?

2. ¿Cómo seleccionaste tu instrumento? ¿Quién influyó en tu elección?

3. Además de la música, ¿qué más aprendes en la Orquesta?

4. ¿Qué es lo que más disfrutas de ser miembro de la Orquesta?

5. ¿Qué comentarios has recibido de otras personas externas a la Orquesta (maestros, vecinos, familia, otros), sobre tu participación en este programa de música?

6. Si pudieras cambiar algo en el programa de la Orquesta Municipal de Música, qué cambiarías?

7. ¿Crees que tu participación en la OMG ha tenido impacto en otras áreas de tu vida? Marca la respuesta más apropiada en cada inciso 
Calificaciones:

Positivo

Sin cambio

Negativo

Si deseas comenta:

Relación con sus padres

Positivo

Sin cambio

Negativo

Si deseas comenta:

Relación con tus maestros

Positivo___ Sin cambio

Si deseas comenta:

Negativo

Relación con compañeros de la orquesta

Positivo Sin cambio

Negativo

Si deseas comenta:

Relación con otros niños y niñas fuera de la orquesta

Positivo

Sin cambio

Negativo

Si deseas comenta:

Tu disciplina para estudiar el instrumento musical

Positivo Sin cambio

Negativo

Si deseas comenta:

Ottos 
8. ¿ ¿Te gustaría continuar tocando con la Orquesta Municipal de Música el próximo año?

$$
\text { Sí No }
$$

¿Por qué?

9. ¿ ¿Te gustaría continuar tu formación como músico profesional?

Si No

¿Por qué?

10. ¿En qué medida aprendes música, de tus compañeros de la OMG? Por favor, encierra en un círculo, la respuesta que consideres más acertada.

Explica tu respuesta
nada
poco
regularmucho 


\section{CUESTIONARIO PARA PADRES DE FAMILIA O TUTORES}

Nombre:

Edad:

Ocupación:

Sexo:

Instrucciones: Por favor, reflexione sobre las siguientes preguntas y responda.

1. ¿Por qué escogió las Escuela Municipal de Músico como la institución de educación musical de sus hijos?

2. En base a la participación de su hijo en las diversas actividades de la Orquesta Municipal, ¿Cómo califica el impacto que han tenido estas en los siguientes aspectos de la vida de su hijo? Por favor marque la respuesta más apropiada en cada inciso.

Calificaciones:

Positivo Sin cambio

Negativo

Si desea, comente:

Relación con sus padres

Positivo Sin cambio

Si desea, comente:

Negativo

Positivo Sin cambio

Negativo

Si desea, comente

Relación con los educadores

Sin cambio

Negativo

Si desea, comente 
Relación con compañeros de la orquesta

Sin cambio

Negativo

Si desea, comente

Relación con otros niños y niñas fuera de la orquesta

Sin cambio

Negativo

Si desea, comente

Otros

3. ¿Qué comentarios ha recibido de personas externas a la OMG (maestros, vecinos, familia, otros), sobre la participación de sus hijos en este programa de música?

4. ¿Cómo describiría lo que expresan sus hijos de su participación en la OMG? ¿Qué opinión tienen ellos sobre el programa?

5. Si usted tuviera la oportunidad de cambiar o mejorar algún aspecto u objetivo de la OMG, ¿cuál sería? 
6. Si fuera el caso, ¿qué no le agrada del programa de Orquesta Municipal de Música?

7. En general, ¿cree que la participación de su hijo en la Orquesta Municipal ha ayudado a evitar las siguientes actividades?

Pertenecer a bandas, pandillas o maras

Sí No ¿por qué?

Uso de sustancias ilegales y drogas

Sí ¿por qué? No

Participación en actividades ilegales

Sí ¿por qué? No

8. Basado en su experiencia con la OMG, ¿qué sugerencias o recomendaciones puede brindar a otros padres interesados en que sus hijos participen en este programa? 
Por favor, encierre en un círculo, la respuesta que considere más acertada para cada una de las preguntas que se le hace
$1=$ nada
$2=$ poco
$3=$ regular
4=mucho

9. ¿Qué tan importante considera la música en el desarrollo de sus hijos?

Explique:

$\begin{array}{llll}1 & 2 & 3 & 4\end{array}$

10. ¿Qué disposición tiene para apoyar a sus hijos en continuar siendo integrantes activos de la Orquesta Municipal de Guatemala durante el próximo año?

Explique:

$\begin{array}{llll}1 & 2 & 3 & 4\end{array}$

